\title{
The Genus Plagiothecium Schimp. (Plagiotheciaceae, Bryophyta) in Eurasia: An Annotated Checklist with Distribution and Ecological Data
}

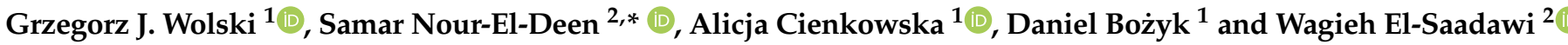 \\ 1 Department of Geobotany and Plant Ecology, Faculty of Biology and Environmental Protection, \\ University of Lodz, Banacha 12/16, 90-237 Łódź, Poland; grzegorz.wolski@biol.uni.lodz.pl (G.J.W.); \\ alicja.cienkowska@unilodz.eu (A.C.); daniel.bozyk@unilodz.eu (D.B.) \\ 2 El-Saadawi Lab, Department of Botany, Faculty of Science, Ain Shams University, Cairo 11566, Egypt; \\ wagelsaadawi@yahoo.com \\ * Correspondence: samarnour11@hotmail.com
}

check for updates

Citation: Wolski, G.J.; Nour-El-Deen, S.; Cienkowska, A.; Bożyk, D.; ElSaadawi, W. The Genus Plagiothecium Schimp. (Plagiotheciaceae, Bryophyta) in Eurasia: An Annotated Checklist with Distribution and Ecological Data. Plants 2021, 10, 868. https://doi.org/ $10.3390 /$ plants10050868

Academic Editor: Harald G.

Zechmeister

Received: 8 March 2021

Accepted: 6 April 2021

Published: 26 April 2021

Publisher's Note: MDPI stays neutral with regard to jurisdictional claims in published maps and institutional affiliations.

Copyright: (c) 2021 by the authors. Licensee MDPI, Basel, Switzerland. This article is an open access article distributed under the terms and conditions of the Creative Commons Attribution (CC BY) license (https:// creativecommons.org/licenses/by/ $4.0 /)$.

\begin{abstract}
An annotated checklist of the pleurocarpous moss genus Plagiothecium in Eurasia is presented for the first time based on a thorough review of the literature. Data have been compiled from previous relevant works conducted on the genus over more than 70 years and published up to the end of June 2020 for 107 Eurasian countries (and islands). Sectional classification is based on molecular phylogeny of the genus published recently. A total of 41 taxa are reported, including 29 species and 12 infraspecific taxa (nine varieties and three forms) belonging to eight sections. The highest numbers of taxa were found in China (20 taxa), the Russian Federation (20 taxa) and Japan (18 taxa), while the smallest numbers of taxa were recorded in the Middle East, Central Asia and the islands area. Not a single species of Plagiothecium was recorded in 26 regions, whereas P. denticulatum, P. nemorale and $P$. cavifolium turned out to be the most widespread species in the entire study area. They were recorded in most of the surveyed countries and islands. For each accepted taxon, information on relevant literature, synonyms, distribution within Eurasia and globally are provided. Comments on each taxon, ecological preferences, and notes on doubtful records are also included. Additionally, distribution maps for each recognised taxon are supplied. This checklist can enlighten and foster a better understanding of the distribution, diversity, and ecology of Plagiothecium in Eurasia and provides an incentive for future research on the genus.
\end{abstract}

Keywords: checklist; ecological preferences; Eurasia; geographic distribution; Musci; Plagiothecium

\section{Introduction}

The pleurocarpous moss genus Plagiothecium Schimp. (Plagiotheciaceae M. Fleisch.) was erected by Schimper and initially described in "Bryologia Europaea" [1] to include plants with more or less flattened, asymmetrical leaves, well-developed decurrent alar cells, and double costae. Over time, the understanding of this genus changed, and many species were excluded from it to create new genera, viz. Herzogiella Broth., Isopterygiella Ignatov \& Ignatova, Isopterygiopsis Z. Iwats., Isopterygium Mitt., Pseudotaxiphyllum Z. Iwats. and Taxiphyllum M. Fleisch. Our understanding of the family Plagiotheciaceae has also changed. It has been treated for a long time as monogeneric, with the single genus Plagiothecium [2-4], but further research using molecular methods [5-7] changed the view of the described genus and the whole family.

Biogeographically, Plagiothecium is a cosmopolitan genus represented in all continents, though varies in diversity and abundance, with largest concentrations in temperate, upland habitats of the Northern Hemisphere. Apart from Asia and Europe [8,9] (which will be discussed in detail later in this paper), the genus has been reported from, for example, Africa: Sub-Saharan Africa [10], tropical Africa [11], Northern Africa [12] and Western 
Africa (Equatorial Guinea) [13]; Antarctica: [14]; Subantarctica: [15]; Australasia: [11,16]; Australia: a single record according to Klazenga [17]; North America: [18,19]; North America North of Mexico: [20,21]; South America: Tropical Andean countries [22]; and Latin America [3].

Ecologically, Plagiothecium is mainly terrestrial, subaquatic, or aquatic; inhabits a variety of substrata, i.e., epilithic (on stones and rocks usually covered with a layer of humus), epixylic (on wood), epigeic (on soil) or epiphytic (usually on the lowest part of tree trunk), see, Figure 1. Species of the genus grow in shaded, moist places in forests, and also found in montane and exposed habitats. They occur mostly in temperate and boreal zones and in tropical uplands; occasionally found in dry and lowland tropics $[3,23]$.
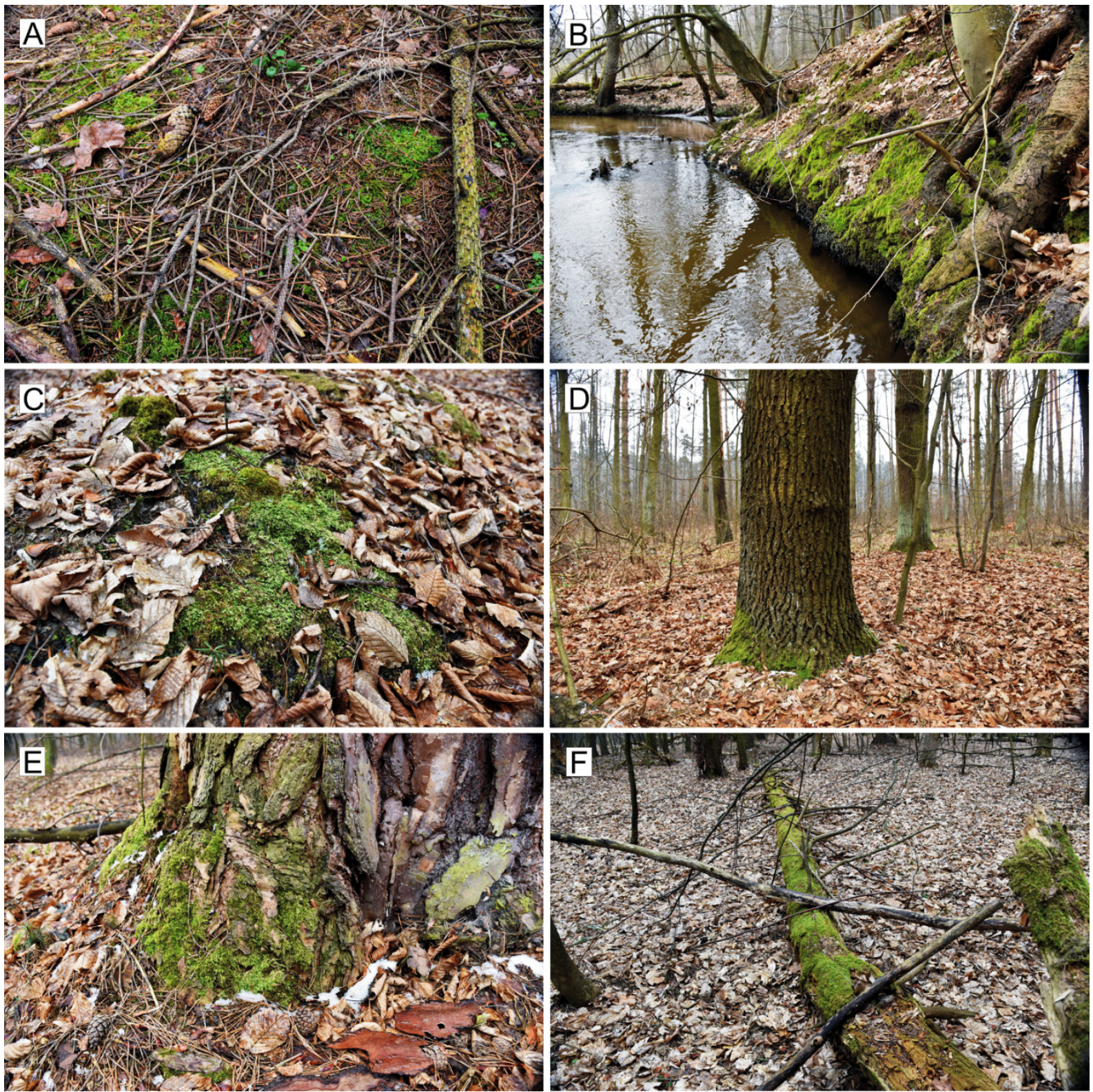

Figure 1. Examples of habitats and substrates covered in central Europe by Plagiothecium species. (A-C). Epigeic habitat: (A). P. curvifolium in the coniferous forest with Picea abies, (B). P. angusticellum and P. longisetum on the river side in the Fraxino-Alnetum phytocoenosis; (C). P. denticulatum in the deciduous forest with Fagus sylvatica; (D,E). Epiphytic habitats: (D). P. denticulatum and P. curvifolium on the lowest part of the trunk of Quercus robur; (E). P. curvifolium on the trunk of Pinus sylvestris); (F). Epixylic habitats: P. laetum on a $\log$ in a deciduous forest (photos by G.J. Wolski, 14 March 2021, Central Poland). 
So far many new taxa have been globally described within the genus; however, the total number of accepted species is still uncertain [24]. Estimates of the number of species have changed over time-from 80-90 species [3] up to 110 species [25]. The latest taxonomic research based on molecular analyses confirmed 70 taxa worldwide $[7,26,27]$, with additional 46 taxa awaiting detailed research to determine their taxonomic status [7].

Since the mid-twentieth century, the number of species of the genus Plagiothecium given for Asia and Europe remained unchanged. For each of these continents, it remained at a similar, fairly low level, containing from a few to over a dozen species [28-33]. This fact was the result of little scientific interest in the described genus which for the past 50 years was rarely the subject of any specified studies, which were usually carried out on national or local level $[18,19,29,30]$. This situation has started to change over the past few years $[7,23,26,27]$.

The genus Plagiothecium is usually described as very variable; however, the reasons for this variability were not analysed $[25,28-30,34]$. Taxonomic studies combined with molecular analyses allowed us not only to describe a number of new taxa but also provided a new perspective on interspecies relationships within the genus. Thanks to this type of research, it has been pointed out that many species are complexes, and the high variability of individual species has been explained [7,23,26,27,35-37].

Currently, research on the genus Plagiothecium focused mainly on the taxonomy of individual taxa or of the whole genus $[7,23,26,27]$. Other aspects as physiology, ecology or chorology were examined in the previous century [38-42] and were usually included as appendices to taxonomic research, i.e., not the main subject of researchers' interest.

The present study was carried out due to the fact that the distribution of Plagiothecium taxa has never been the subject of specific studies and the fact that in recent years the taxonomic status of many species has changed. The purpose of this article is to create a checklist for Plagiothecium in Eurasia and to describe the distribution of the Eurasian taxa of this genus. To attain this goal, it was decided to amass and systematise the available knowledge in relevant literature in order to (1) identify the names of all taxa known to occur in each country (island), (2) clarify the status of names and taxa which are accepted, (3) analyse the geographic distribution, and (4) estimate species richness of Plagiothecium in Eurasia. This study is not intended to be a taxonomic revision of Plagiothecium, however it provides the latest status for all recognised taxa with their geographical distribution.

We tried our utmost to compile all of the relevant information to approach the purpose for this study. However, the current knowledge of Plagiothecium distribution and species diversity in Eurasia (and other continents as well) is still somewhat biased toward some countries while contains gaps in others due to complete lack of data or of reliable data or insufficient sampling. Not to mention the currently accelerating rate of changes in taxonomic status of many taxa as a consequence of molecular studies. The present checklist can serve as a new starting point for further research on the genus in these countries, which will likely result in addition of new records or perhaps new taxa.

The authors inviting comments and would appreciate notifications of additions and corrections to update the present checklist. Please address relevant information to the corresponding author.

\section{Results and Discussion}

\subsection{General Results}

The present checklist includes 41 taxa, comprising 29 species, nine varieties and three forms belonging to eight sections. For two countries (Palestine and Timor-Leste), no study confirming or excluding any species from the genus described could be found. The rest of Eurasia is quite well explored and widely described in terms of mosses (Table 1). 
Table 1. Abbreviation of countries/regions treated in the checklist, with sources of the regional information.

\begin{tabular}{|c|c|c|c|}
\hline No. & Country/Region & Abbreviation & Main Source(s) of Information \\
\hline 1. & Afghanistan & AFG & [43-46] \\
\hline 2. & Albania & ALB & {$[9,47-50]$} \\
\hline 3. & Andorra & AND & {$[9,47,48,51,52]$} \\
\hline 4. & Armenia & ARM & {$[32,53]$} \\
\hline 5. & Austria & AUT & {$[7,9,26,27,48,54]$} \\
\hline 6. & Azerbaijan & AZE & [32] \\
\hline 7. & Azores (Portugal) & $\mathrm{AZO}$ & {$[9,27,47,48,55-57]$} \\
\hline 8. & Bahrain & BAH & {$[43,45]$} \\
\hline 9. & Balearic Islands (Spain) & BAL & {$[47,48,58]$} \\
\hline 10. & Bangladesh & BAN & {$[59,60]$} \\
\hline 11. & Belarus & BLR & {$[9,32,48,61]$} \\
\hline 12. & Belgium & BGM & {$[7,9,27,48,62]$} \\
\hline 13. & Bhutan & BHU & {$[7,63,64]$} \\
\hline 14 & Borneo (Indonesia, Malaysia, Brunei) & BOR & {$[65,66]$} \\
\hline 15. & Bosnia and Herzegovina & $\mathrm{BIH}$ & {$[9,26,47-49]$} \\
\hline 16. & Brunei Darussalam & BRN & [67] \\
\hline 17. & Bulgaria & BUL & {$[9,47-49,68]$} \\
\hline 18. & Cambodia & CBD & [69-73] \\
\hline 19. & Canary Islands (Spain) & $\mathrm{CNY}$ & {$[9,47,48,74,75]$} \\
\hline 20. & Channel Islands (United Kingdom) & $\mathrm{CHI}$ & {$[9,48]$} \\
\hline 21. & China & $\mathrm{CHN}$ & {$[7,27,36,64,66,76-80]$} \\
\hline 22. & Corsica (France) & COR & {$[9,47,48,62]$} \\
\hline 23. & Crete (Greece) & CRE & {$[47,48,81]$} \\
\hline 24. & Croatia & $\mathrm{CRO}$ & {$[9,47-49,82,83]$} \\
\hline 25. & Cyprus & CYP & {$[43,47,48]$} \\
\hline 26. & Czech Republic & CZE & {$[7,9,26,27,48,84]$} \\
\hline 27. & Democratic People's Republic of Korea (North Korea) & $\mathrm{NKO}$ & {$[7,64,66,78,85,86]$} \\
\hline 28. & Denmark & DEN & {$[7,9,27,30,48,87]$} \\
\hline 29. & Estonia & EST & {$[9,27,32,48,88]$} \\
\hline 30. & Faroe Islands (Denmark) & FRO & {$[7,9,48,89,90]$} \\
\hline 31. & Finland & FIN & {$[7,9,26-28,48,91-93]$} \\
\hline 32. & France & FRA & {$[7,9,27,47,48,78,94]$} \\
\hline 33. & Germany & GER & {$[7,9,26,27,48,95-98]$} \\
\hline 34. & Greece & GRC & {$[9,47-49]$} \\
\hline 35. & Hungary & HUN & {$[7,9,26,27,48,99-101]$} \\
\hline 36. & Iceland & ICE & {$[7,9,48,102]$} \\
\hline 37. & India & IND & {$[7,27,64,78,103,104]$} \\
\hline 38. & Indonesia & IDN & {$[7,105]$} \\
\hline 39. & Iraq & IRQ & {$[43,45,106-108]$} \\
\hline 40. & Ireland & IRE & {$[9,25,48,109]$} \\
\hline 41. & Islamic Republic of Iran & IRN & {$[7,27,43,45,110,111]$} \\
\hline 42. & Israel & ISR & {$[43,45,47,112,113]$} \\
\hline 43. & Italy & ITA & {$[7,9,27,47,48,114-117]$} \\
\hline 44. & Japan & JAP & {$[7,27,29,33,34,64,66,78,118,119]$} \\
\hline 45. & Jordan & JOR & {$[43,45,47]$} \\
\hline 46. & Kazakhstan & KAZ & {$[32,48]$} \\
\hline 47. & Kosovo & KOS & {$[9,48,120]$} \\
\hline 48. & Kuwait & KUW & {$[43,45,121,122]$} \\
\hline 49. & Kyrgyzstan & KGZ & [32] \\
\hline 50. & Lao People's Democratic Republic & $\mathrm{LAO}$ & {$[72,78,123]$} \\
\hline 51. & Latvia & LAV & {$[7,9,27,32,48,124,125]$} \\
\hline 52. & Lebanon & LBN & {$[43,45,47]$} \\
\hline 53. & Liechtenstein & LIE & {$[9,48,126]$} \\
\hline 54. & Lithuania & LTU & {$[9,27,32,48,127,128]$} \\
\hline 55. & Luxembourg & LUX & {$[9,48,129,130]$} \\
\hline 56. & Madeira (Portugal) & MDR & {$[9,27,47,48,51,131,132]$} \\
\hline 57. & Malaysia & MLY & [133] \\
\hline 58. & Maldives & MDV & {$[134,135]$} \\
\hline 59. & Malta & MAL & {$[47,48,136,137]$} \\
\hline 60. & Monaco & $\mathrm{MCO}$ & [48] \\
\hline 61. & Mongolia & MON & {$[138,139]$} \\
\hline 62. & Montenegro & MNE & [9,47-49] \\
\hline 63. & Myanmar (Burma) & MYA & {$[72,140]$} \\
\hline 64. & Nepal & NEP & {$[7,27,64,141,142]$} \\
\hline 65. & Netherlands & NET & {$[7,9,48,143,144]$} \\
\hline
\end{tabular}


Table 1. Cont.

\begin{tabular}{|c|c|c|c|}
\hline No. & Country/Region & Abbreviation & Main Source(s) of Information \\
\hline 66. & Norway & NOR & {$[7,9,26,27,48]$} \\
\hline 67. & North Macedonia (formerly Macedonia) & MKD & {$[9,47-49,145,146]$} \\
\hline 68. & Oman & OMA & {$[43,45,122]$} \\
\hline 69. & Pakistan & PAK & [147-151] \\
\hline 70. & Palestine & PAL & No information available \\
\hline 71. & Philippines & PHI & {$[7,66,152,153]$} \\
\hline 72. & Poland & POL & {$[7,9,26,27,48,154]$} \\
\hline 73. & Portugal & POR & {$[9,27,47,48,51,155,156]$} \\
\hline 74. & Qatar & QAT & {$[43,45,157]$} \\
\hline 75. & Republic of Korea (South Korea) & SKO & {$[7,64,66,78,86]$} \\
\hline 76. & Republic of Moldova & MOL & {$[9,32,48]$} \\
\hline 77. & Romania & ROM & {$[9,48,49,158]$} \\
\hline 78. & Russia Federation & RUS & {$[7,9,26,27,32,48,64,78,159-162]$} \\
\hline 79. & San Marino (Italy) & SMR & {$[9,48]$} \\
\hline 80. & Sardinia (Italy) & SAR & {$[9,47,48]$} \\
\hline 81. & Saudi Arabia & SAU & {$[43,45,122]$} \\
\hline 82. & Serbia & SRB & {$[9,47-49]$} \\
\hline 83. & Sicily (Italy) & SIC & {$[9,47,48]$} \\
\hline 84. & Singapore & SIN & [133] \\
\hline 85. & Slovakia & SVK & {$[7,9,27,48,163,164]$} \\
\hline 86. & Slovenia & SVN & {$[9,47-49,165,166]$} \\
\hline 87. & South Georgia & GEO & {$[27,32]$} \\
\hline 88. & Spain & SPA & {$[9,27,47,48,51,167]$} \\
\hline 89. & Sri Lanka & SRL & {$[7,168-170]$} \\
\hline 90. & Sumatra (Indonesia) & SUM & {$[66,105]$} \\
\hline 91. & Svalbard (Norway) & SVA & {$[7,9,26,48,171-173]$} \\
\hline 92. & Sweden & SWE & {$[7,9,26,27,48,174,175]$} \\
\hline 93. & Switzerland & SWI & {$[7,9,27,48,176,177]$} \\
\hline 94. & Syrian Arab Republic & SYR & {$[43,45,47]$} \\
\hline 95. & Taiwan & TAI & {$[7,66,77,78,178]$} \\
\hline 96. & Tajikistan & TZK & [32] \\
\hline 97. & Thailand & THA & {$[66,72,179]$} \\
\hline 98. & Timor-Leste & TLS & No information available \\
\hline 99. & Turkey & TUR & {$[7,9,27,43,45,47-49,180-182]$} \\
\hline 100 & Turkmenistan & TKM & [32] \\
\hline 101 & Ukraine & UKR & {$[9,26,32,48,183-185]$} \\
\hline 102 & United Arab Emirates & UAE & {$[43,45,122]$} \\
\hline 103. & United Kingdom & GRB & {$[7,9,25,27,48,109]$} \\
\hline 104. & Uzbekistan & UZB & [32] \\
\hline 105. & Vatican City & VAT & {$[48,186,187]$} \\
\hline 106. & Vietnam & VIE & {$[72,123,188,189]$} \\
\hline 107. & Yemen & YEM & {$[43,45,122,190]$} \\
\hline
\end{tabular}

All across Eurasia, the genus Plagiothecium is quite widely, but unevenly distributed (Figures S1-S4). An analysis of the species richness for individual countries and islands has shown that in the area of the Middle East (e.g., Iraq, Israel, Jordan, Kuwait, Lebanon and Qatar), Central Asia (Kazakhstan, Kyrgyzstan, Tajikistan, Turkmenistan and Uzbekistan), and small islands (e.g., the Azores, Balearic Islands, Canary Islands, as well as Crete, Malta and Sardinia) taxa from the genus Plagiothecium were not recorded at all or are sporadically recorded (Figures S2 and S3). Further analysis also showed that in 26 countries (25\% of all analysed countries) not a single taxon of the concerned genus was recorded. Only one species was recorded in 11 countries $(8 \%)$, two and three taxa were recorded in six regions (6\% among all analysed countries and islands) (Table 2). 


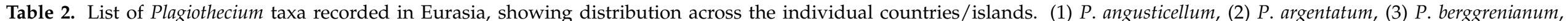

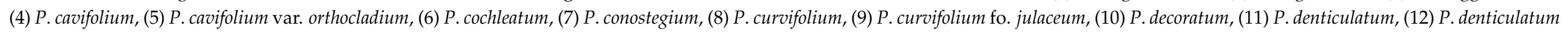

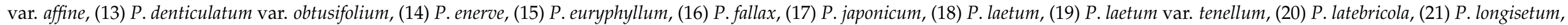

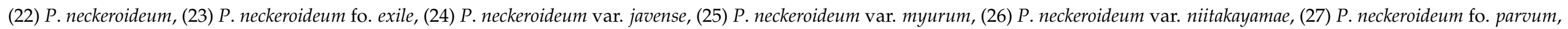

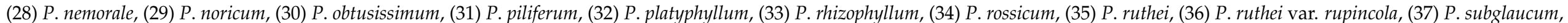

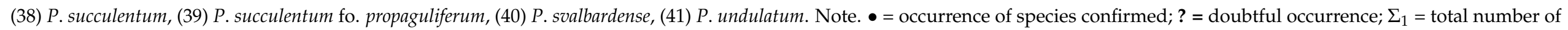
Plagiothecium taxa recorded per country/island; $\Sigma_{2}=$ total number of records for each taxon in Eurasia.

\begin{tabular}{|c|c|c|c|c|c|c|c|c|c|c|c|c|c|c|c|c|c|c|c|c|c|c|c|c|c|c|c|c|c|c|c|c|c|c|c|c|c|c|c|c|c|c|}
\hline \multirow{2}{*}{ Countries/Islands } & \multicolumn{41}{|c|}{ Plagiothecium Taxa Recorded in Eurasia } & \multirow{2}{*}{$\Sigma_{1}$} \\
\hline & 1 & 2 & 3 & 4 & 5 & 6 & 7 & 8 & 9 & 10 & 11 & 12 & 13 & 14 & 15 & 16 & 17 & 18 & 19 & 20 & 21 & 22 & 23 & 24 & 25 & 26 & 27 & 28 & 29 & 30 & 31 & 32 & 33 & 34 & 35 & 36 & 37 & 38 & 39 & 40 & 41 & \\
\hline Afghanistan & & & & & & & & & & & & & & & & & & & & & & & & & & & & & & & & & & & & & & & & & & - \\
\hline Albania & & & & • & & & & • & & & - & & & & & & & - & & & & & & & & & & - & & & & & & & & & & $\bullet$ & & & & 6 \\
\hline Armenia & & & & & & & & & & & $\bullet$ & & & & & & & & & & & & & & & & & $\bullet$ & & & & & & & & & & & & & & 2 \\
\hline Austria & & & & $\bullet$ & & & & $\bullet$ & & & - & & $\bullet$ & & & & & $\bullet$ & & $\bullet$ & $\bullet$ & $\bullet$ & & & & & & $\bullet$ & $\bullet$ & & & $\bullet$ & & & $\bullet$ & $\bullet$ & & $\bullet$ & $\bullet$ & & $\bullet$ & 16 \\
\hline Azerbaijan & & & & $\bullet$ & & & & & & & $\bullet$ & & & & & & & $\bullet$ & & & & & & & & & & $\bullet$ & & & & & & & & & & & & & $\bullet$ & 5 \\
\hline Azores & & & & & & & & & & & & & & & & & & & & & $\bullet$ & & & & & & & $\bullet$ & & & & & & & & & & $?$ & & & & 3 \\
\hline Balearic Islands & & & & & & & & & & & & & & & & & & & & & & & & & & & & & & & & & & & & & & & & & & - \\
\hline Bangladesh & & & & & & & & & & & $\bullet$ & & & & & & & & & & & & & & & & & & & & & & & & & & & & & & & 1 \\
\hline Belarus & & & & $\bullet$ & & & & & & & - & & & & & & & $\bullet$ & & - & & & & & & & & $\bullet$ & & & & & & & $\bullet$ & & & $?$ & & & $\bullet$ & 8 \\
\hline Belgium & & & & $\bullet$ & & & & $\bullet$ & & & $\bullet$ & & & & & & & $\bullet$ & $\bullet$ & $\bullet$ & $\bullet$ & & & & & & & $\bullet$ & & & & & & & & & & $\bullet$ & & & $\bullet$ & 10 \\
\hline Bhutan & & & & $\bullet$ & & & & & & $\bullet$ & & & & & $\bullet$ & & & & & & & $\bullet$ & & & $\bullet$ & & & $\bullet$ & & & & & & & & & & & & & & 6 \\
\hline Bosnia and Herzegovina & & & & $\bullet$ & & & & $\bullet$ & & & $\bullet$ & & & & & & & $\bullet$ & & & & & & & & & & $\bullet$ & & & & & & & & & & $\bullet$ & & & $\bullet$ & 7 \\
\hline Brunei Darussalam & & & & & & & & & & & & & & & & & & & & & & & & & & & & & & & & & & & & & & & & & & - \\
\hline Bulgaria & & & & $\bullet$ & & & & $\bullet$ & & & $\bullet$ & & $\bullet$ & & & & & $\bullet$ & & & & & & & & & & $\bullet$ & & & & $\bullet$ & & & $\bullet$ & & & $\bullet$ & & & $\bullet$ & 10 \\
\hline Cambodia & & & & & & & & & & & & & & & & & & & & & & & & & & & & & & & & & & & & & & & & & & - \\
\hline Channel Islands & & & & & & & & $\bullet$ & & & - & & & & & & & & & & & & & & & & & $\bullet$ & & & & & & & & & & $\bullet$ & & & $\bullet$ & 5 \\
\hline China & & $\bullet$ & & $\bullet$ & & & & $\bullet$ & & & $\bullet$ & & $\bullet$ & $\bullet$ & $\bullet$ & & & $\bullet$ & & $\bullet$ & $\bullet$ & $\bullet$ & & & • & - & & • & & & $\bullet$ & $\bullet$ & - & & - & & & • & & & $\bullet$ & 20 \\
\hline Corsica & & & & • & & & & • & & & - & & & & & & & & & & & & & & & & & - & & & $\bullet$ & • & & & & & & $\bullet$ & & & & 7 \\
\hline Crete & & & & & & & & & & & & & & & & & & & & & & & & & & & & & & & & & & & & & & & & & & - \\
\hline Croatia & & & & • & & & & $\bullet$ & & & - & & & & & & & • & & & & & & & & & & • & & & & $\bullet$ & & & & & & & & & $\bullet$ & 7 \\
\hline Cyprus & & & & & & & & & & & & & & & & & & & & & & & & & & & & & & & & & & & & & & & & & & - \\
\hline
\end{tabular}


Table 2. Cont.

\begin{tabular}{|c|c|c|c|c|c|c|c|c|c|c|c|c|c|c|c|c|c|c|c|c|c|c|c|c|c|c|c|c|c|c|c|c|c|c|c|c|c|c|c|}
\hline \multirow{2}{*}{ Countries/Islands } & \multicolumn{38}{|c|}{ Plagiothecium Taxa Recorded in Eurasia } & \multirow{2}{*}{$\Sigma_{1}$} \\
\hline & 1 & $\begin{array}{ll}2 & 3\end{array}$ & $\begin{array}{ll}3 & 4 \\
\end{array}$ & 5 & 6 & 7 & 8 & 9 & 10 & 11 & 12 & $13 \quad 14$ & 15 & 16 & 17 & 18 & 19 & 20 & 21 & 22 & 23 & 24 & 25 & 26 & 27 & $28 \quad 2$ & $29 \quad 3$ & $\begin{array}{ll}30 & 31\end{array}$ & 32 & 33 & 34 & 35 & 36 & 37 & 38 & 39 & 40 & 41 & \\
\hline Czech Republic & $\bullet$ & & $\bullet$ & & & & $\bullet$ & & & $\bullet$ & & $\bullet$ & & & & $\bullet$ & & $\bullet$ & & $\bullet$ & & & & & & $\bullet$ & & & $\bullet$ & & & $\bullet$ & $\bullet$ & & $\bullet$ & $\bullet$ & & $\bullet$ & 15 \\
\hline $\begin{array}{l}\text { Democratic People's } \\
\text { Republic of Korea }\end{array}$ & & & $\bullet$ & & & & & & & $\bullet$ & & & $\bullet$ & & & - & & & & $\bullet$ & & & & & & - & & $\bullet$ & $\bullet$ & & & & & & $\bullet$ & & & & 9 \\
\hline Denmark & & & - & & & & - & & & - & & & & & & - & & - & - & & & & & & & - & & - & - & & & - & & & • & - & & - & 13 \\
\hline Estonia & - & & - & & & & - & & & - & & & & & & - & & - & - & & & & & & & - & & & & & & • & & & • & & & - & 11 \\
\hline Faroe Islands & & & - & - & & & & & & - & & & & & & & & & & & & & & & & - & & & & & & & & & - & & & - & 6 \\
\hline Finland & & & - & • & & & - & & & - & & - & & & & - & & - & - & & & & & & & - & & - & - & & & • & & & - & & & - & 14 \\
\hline France & & & $\bullet$ & & & & $\bullet$ & & & $\bullet$ & & $\bullet$ & & & & $\bullet$ & & $\bullet$ & $\bullet$ & & & & & & & $\bullet$ & & $\bullet$ & $\bullet$ & & & $\bullet$ & $\bullet$ & & $\bullet$ & & & $\bullet$ & 14 \\
\hline Germany & & & $\bullet$ & & & & $\bullet$ & & & $\bullet$ & $\bullet$ & - & & & & $\bullet$ & & $\bullet$ & $\bullet$ & $\bullet$ & & & & & & $\bullet$ & & & $\bullet$ & & & $\bullet$ & $\bullet$ & & $\bullet$ & $\bullet$ & & $\bullet$ & 16 \\
\hline Greece & & & - & & & & - & & & - & & & & & & - & & & & & & & & & & - & & & $\bullet$ & & & & & & $\bullet$ & & & & 7 \\
\hline Hungary & $\bullet$ & & $\bullet$ & & & & $\bullet$ & & & $\bullet$ & & $\bullet$ & & & & $\bullet$ & & $\bullet$ & & & & & & & & $\bullet$ & & & $\bullet$ & & & $\bullet$ & & & $\bullet$ & & & $\bullet$ & 12 \\
\hline Iceland & & & - & & & & & & & - & & - & & & & & & & & & & & & & & & & & & & & & & & $\bullet$ & & & & 4 \\
\hline India & & - & - & & • & & & & & - & & & - & & & & & & - & - & & & - & & & - & & & & & & & & & & & & & 9 \\
\hline Indonesia & & & & & & & & & & & & & & & & & & & & - & & - & & & & & & & & & & & & & & & & & 2 \\
\hline Iraq & & & & & & & & & & $\bullet$ & & & & & & & & & & & & & & & & & & & & & & & & & & & & & 1 \\
\hline Ireland & & & - & & & & $\bullet$ & & & $\bullet$ & & - & & & & - & & $\bullet$ & & & & & & & & $\bullet$ & & - & - & & & $\bullet$ & & & $\bullet$ & & & $\bullet$ & 12 \\
\hline Islamic Republic of Iran & & & - & & & & & & & $\bullet$ & & - & & & & - & & & $\bullet$ & & & & & & & $\bullet$ & & & - & & & & & & $\bullet$ & & & $\bullet$ & 9 \\
\hline Japan & & & $\bullet$ & & & $\bullet$ & $\bullet$ & & & $\bullet$ & & $\bullet$ & $\bullet$ & $\bullet$ & $\bullet$ & $\bullet$ & & $\bullet$ & $\bullet$ & - & & & & - & & $\bullet$ & $\bullet$ & $\bullet \quad \bullet$ & $\bullet$ & & & $\bullet$ & & & & & & & 18 \\
\hline Jordan & & & & & & & & & & & & & & & & & & & & & & & & & & & & & & & & & & & & & & & - \\
\hline Kazakhstan & & & - & & & & & & & $\bullet$ & & & & & & $\bullet$ & & & & & & & & & & & & & & & & & & & & & & & 3 \\
\hline Kosovo & & & & & & & $\bullet$ & & & $\bullet$ & & - & & & & - & & & & & & & & & & $\bullet$ & & & $\bullet$ & & & & & & $\bullet$ & & & & 7 \\
\hline Kuwait & & & & & & & & & & & & & & & & & & & & & & & & & & & & & & & & & & & & & & & - \\
\hline Kyrgyzstan & & & & & & & & & & $\bullet$ & & & & & & $\bullet$ & & $\bullet$ & & & & & & & & & & & & & & & & & & & & & 3 \\
\hline $\begin{array}{c}\text { Lao People's } \\
\text { Democratic Republic }\end{array}$ & & & $\bullet$ & & & & & & & & & & & & & & & & & & & & & & & & & & & & & & & & & & & & 1 \\
\hline Latvia & - & & - & & & & $\bullet$ & & & $\bullet$ & & & & & & - & & $\bullet$ & & & & & & & & • & & • & & & & $\bullet$ & & & $\bullet$ & $\bullet$ & & • & 12 \\
\hline Lebanon & & & & & & & & & & & & & & & & & & & & & & & & & & & & & & & & & & & & & & & - \\
\hline
\end{tabular}


Table 2. Cont.

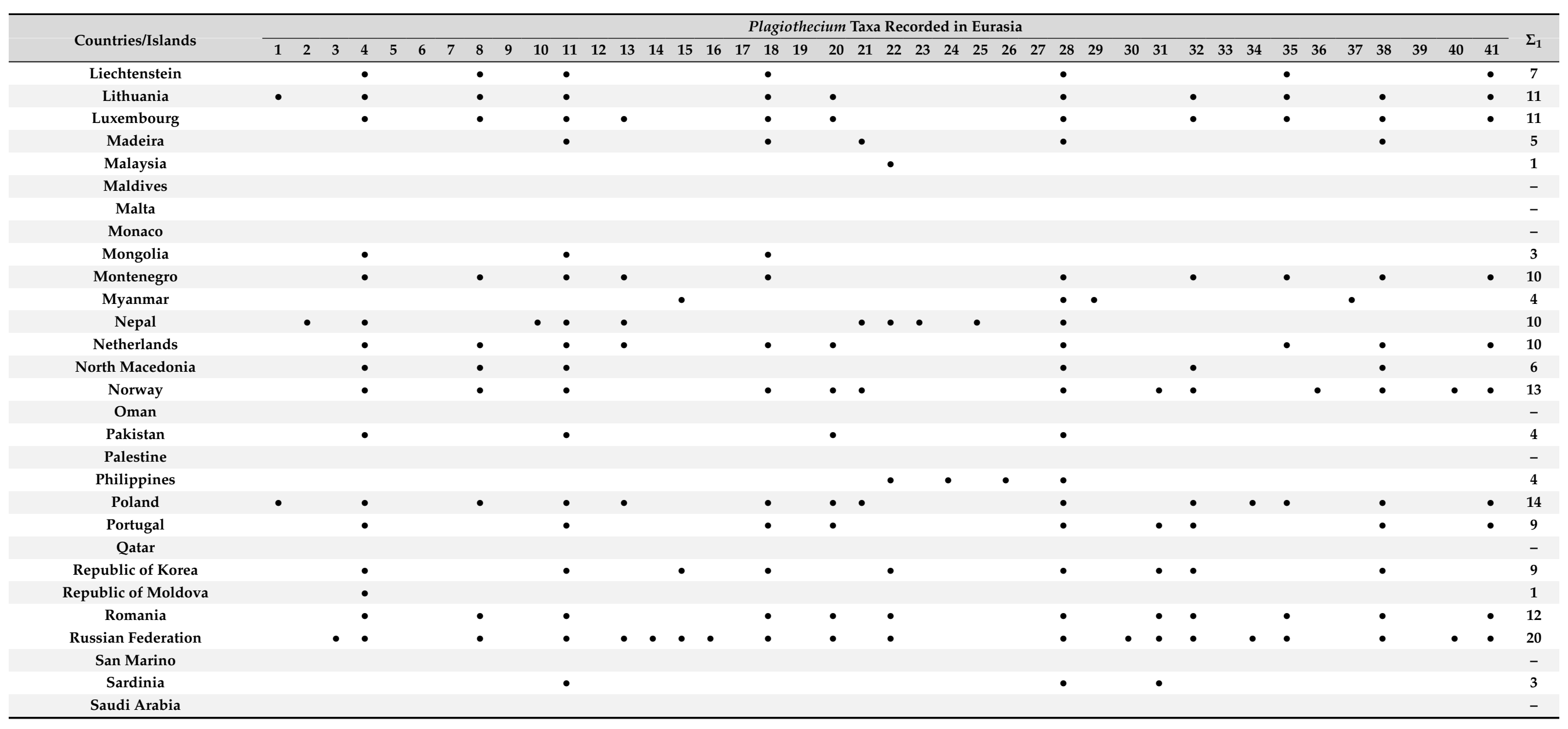


Table 2. Cont.

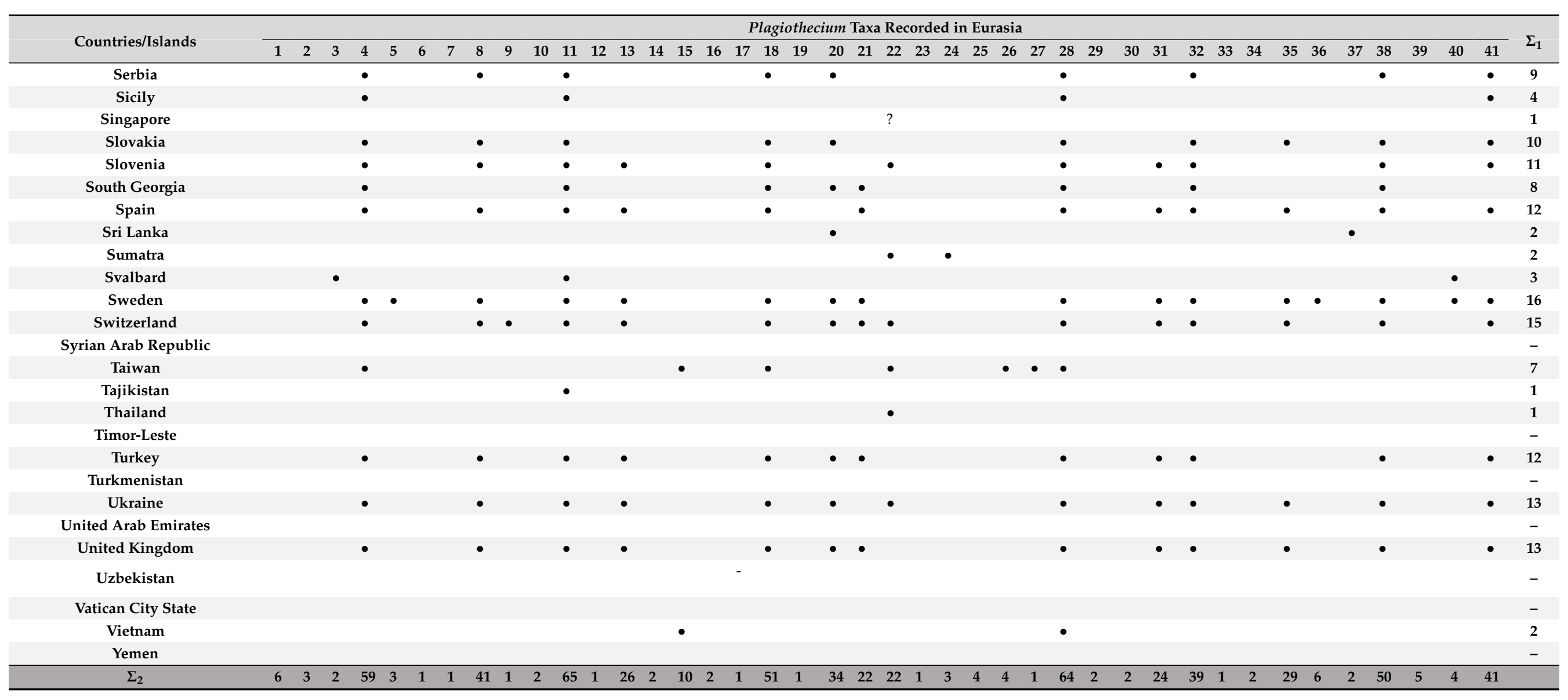


The highest number of taxa was recorded in eight quite large countries ( $8 \%$ among all analysed): in China (20 taxa), the Russian Federation (20), Japan (18); Austria, Germany, Sweden (16), Czech Republic and Switzerland (15 taxa each) (Table 2, Figures S1-S4).

The conducted analysis of the frequency of occurrence of individual species showed that species with a limited range are a majority in the studied genus. Twenty-six taxa $(60 \%$ of all) were reported only from one to five countries, and in the Eurasia they were recognised to be very rare. Wherein, 12 of them (e.g., P. argentatum, P. cochleatum, P. conostegium, $P$. decoratum, P. subglaucum) (Figure S1) were listed only in Asia. The smallest number of taxa in this group (P. berggrenianum, P. enerve, $P$. fallax, P. obtusissimum and $P$. rossicum) was reported both in Asia and Europe (Table 2). The frequency analysis also indicated that common species are the least numerous group. The species with the widest range were: $P$. denticulatum, listed in 65 countries and islands (65\% of all analysed), P. nemorale $(64,62 \%)$, and P. cavifolium $(59,60 \%)$, they were considered as common in the study area (Table 2, Figures S2 and S4).

\subsection{Annotations by Taxon}

- Annotations to the following list of Plagiothecium taxa include brief description for each taxon, with comments on nomenclature and taxonomic status (when necessary), ecological preferences, and geographic distribution inside and outside Eurasia (if available).

- Taxon distribution per country in Eurasia is given in detail in Appendix B, with all available literature sources.

- We did not make any broad attempt to provide an exhaustive list of records for all countries in each continent (outside Eurasia), but we gave a general overview of the geographic distribution outside the study area based on the selected references. As far as we know, none of the 41 taxa listed here have been reported from Antarctica [14] or Australia [17].

1. Plagiothecium angusticellum G.J. Wolski \& P. Nowicka-Krawczyk 2020-a mediumsized plant, with asymmetrical leaves, not shrunken when dry; an acuminate, gently curved, not serrated apex; tight areolation, created with long and narrow leaf cells which do not form regular rows. This combination of features made it possible to distinguish $P$. angusticellum from similar and closely related species such as P. cavifolium, P. nemorale, and P. longisetum [27]. Ecology. From Poland (from where it was described), this species was recorded mainly in deciduous forests (e.g., eutrophic swamp forests Ribeso nigri-Alnetum Sol.-Górn. (1975) 1987, wet alder riparian forests Fraxino-Alnetum W. Mat. 1952, beech forests Luzulo pilosae-Fagetum W. Mat. et A. Mat. 1973, oaklinden-hornbeam forests Tilio-Carpinetum Tracz. 1962) in epigeic, epiphytic and epilithic habitats. Distribution. Apart from Central Europe, this species is also reported from North America (USA) [191].

2. Plagiothecium argentatum (Mitt.) Q. Zuo 2011-described as Hypnum argentatum by Mitten [192], transferred to the genus Struckia by Müller [193], and finally (based on DNA analysis) incorporated into the genus Plagiothecium [36], its integration in this genus was confirmed by other researchers (e.g., [7,23]). A pale green, julaceous plant, with symmetric, concave, plicate, long, non-decurrent leaves, with a serrulate or entire margin, and quadrate alars; it is characterised by quite an unusual (for a member of the genus Plagiothecium) set of features. Most of these features place P. argentatum well in the described genus, but serrulate margins, absence of decurrency and quadrate alars seem to exclude this species from the genus Plagiothecium. This large morphological separateness resulted in the placement of this species (as $P$. enerve) in a separate section of Struckia [23]. Ecology. The species was recorded in epiphytic and epixylic habitats [7]. Distribution. So far, recorded from East and South Asia.

3. Plagiothecium berggrenianum Frisvoll 1981-a medium-sized to large, julaceous, crowded plant; leaves symmetrical, very concave, ovate, long decurrent, and an abruptly narrowed to hooked apex; leaf cells long and narrow, thick-walled; capsules straight and 
erect. This circumpolar species was described by Frisvoll [171], and is easily distinguishable from other species by leaves with recurved margins and by the shape of its apex, as well as well-developed alar regions. Plagiothecium berggrenianum is similar to $P$. svalbardense, but the former is longer, with elliptical, plicate leaves, and broadly recurved margins. Wynns [7] states that P. berggrenianum is a possible hybrid. Ecology. This species is recorded in epigeic, epilithic and epixylic habitats $[26,171,172]$. It is found in swales, tundra, and cliffs; low to moderate elevations [21]. Distribution. Apart from Eurasia, it is also reported from North America (Canada, Greenland, USA) $[7,26,172]$.

4. Plagiothecium cavifolium (Brid.) Z. Iwats. 1970-Iwatsuki [29] selected this name for the species previously known as $P$. roeseanum [1]. A small to medium-sized, pale green to yellowish green, glossy plant in dense mats (Figure 2); ascending to erect, stems julaceous more or less; imbricate, ovate to elliptical, symmetric, concave leaves (Figure 3), often with a curved apex; cells linear-rhomboidal, long and narrow (Figure 4). Ecology. This species is found in shaded locations in low to high elevations [21] and recorded in epigeic, epilithic, epixylic and epiphytic habitats (e.g., [25,28-30,34,62,79,194-199]). Distribution. Apart from Eurasia, this species is also reported from Africa (Tunisia) [47]; North America (Canada, Falkland Islands, Greenland, USA) $[7,21,23,25,79]$.

5. Plagiothecium cavifolium var. orthocladium (Schimp.) Z. Iwats. 1970-Iwatsuki [29] selected this name for the variety previously known as P. orthocladium [1], and also reported on a relationship between this taxon and $P$. nemorale fo. japonicum (currently P. japonicum) as well as P. succulentum. Wynns [7] mentioned difficulty in distinguishing this taxon, adding that he used this name for olivaceous, boreal specimens, with crispate and spreading leaves. Ecology. This taxon is recorded in epilithic habitat. Distribution. Apart from Europe (Nordic countries), this taxon is also reported from North America (Canada, Greenland) [7].

6. Plagiothecium cochleatum Dixon 1938-a dark green plant; leaves loosely imbricated, concave, plicate, with rigid areolation, and quite well-developed alar decurrencies. Wynn [7] indicates that P. cochleatum is similar to P. cavifolium and may be confused with this species. Ecology. It is a rare species, present in disjunct Alpine and Himalayan habitats [23]. Distribution. So far, it is reported from Asia (India).

7. Plagiothecium conostegium Herzog 1916-Suzuki [119] recorded this taxon from Japan. Considering the features and pictures published by Suzuki [119] in particular: Asymmetric, in dry condition shrunken leaves, long-hexagonal cells, we believe that the taxon described by Suzuki [119] looks more like P. longisetum. This requires checking herbarium materials, but at this stage, we consider the presence of $P$. conostegium doubtful in Eurasia. Ecology. In Central and South America, it is recorded as a forest species mostly growing on epigeic, epilithic, epiphytic and epixylic habitats $[3,7]$. Distribution. Apart from Asia (Japan) [119], the species is reported by Wynns [7] as a mountain species from Central America and Northern South America (Bolivia, Ecuador, Guatelama, Mexico, Peru) and also present at high elevations in North America, the Dominican Republic, Northern Andes and Tierra del Fuego [3].

8. Plagiothecium curvifolium Schlieph. ex Limpr. 1897-a small to medium-sized plant, green to yellowish green, glossy (Figure 2); leaves broadly lanceolate to lanceolate, not concave, asymmetric, sometimes downward curving; alar decurrencies wide, hyaline (Figure 3), sometimes even inflated; capsules curved and inclined to horizontal. These features distinguish this species from other closely related species (e.g., P. laetum). Ireland [18] and Iwatsuki [29] (and many after them) did not recognise $P$. curvifolium and P. laetum as separate species, but DNA analysis clearly proves this $[7,23]$. Ecology. It is recorded in epigeic, epilithic, epixylic and epiphytic habitats (e.g., [25,28-30,34,79,194,200]). Distribution. The species is common in lowland areas [25]. Outside Eurasia, it is reported from Africa [29] but its presence in North 
Africa considered doubtful by Ros et al. [12]. It is also reported from North America (Canada, USA) [7,25,79].
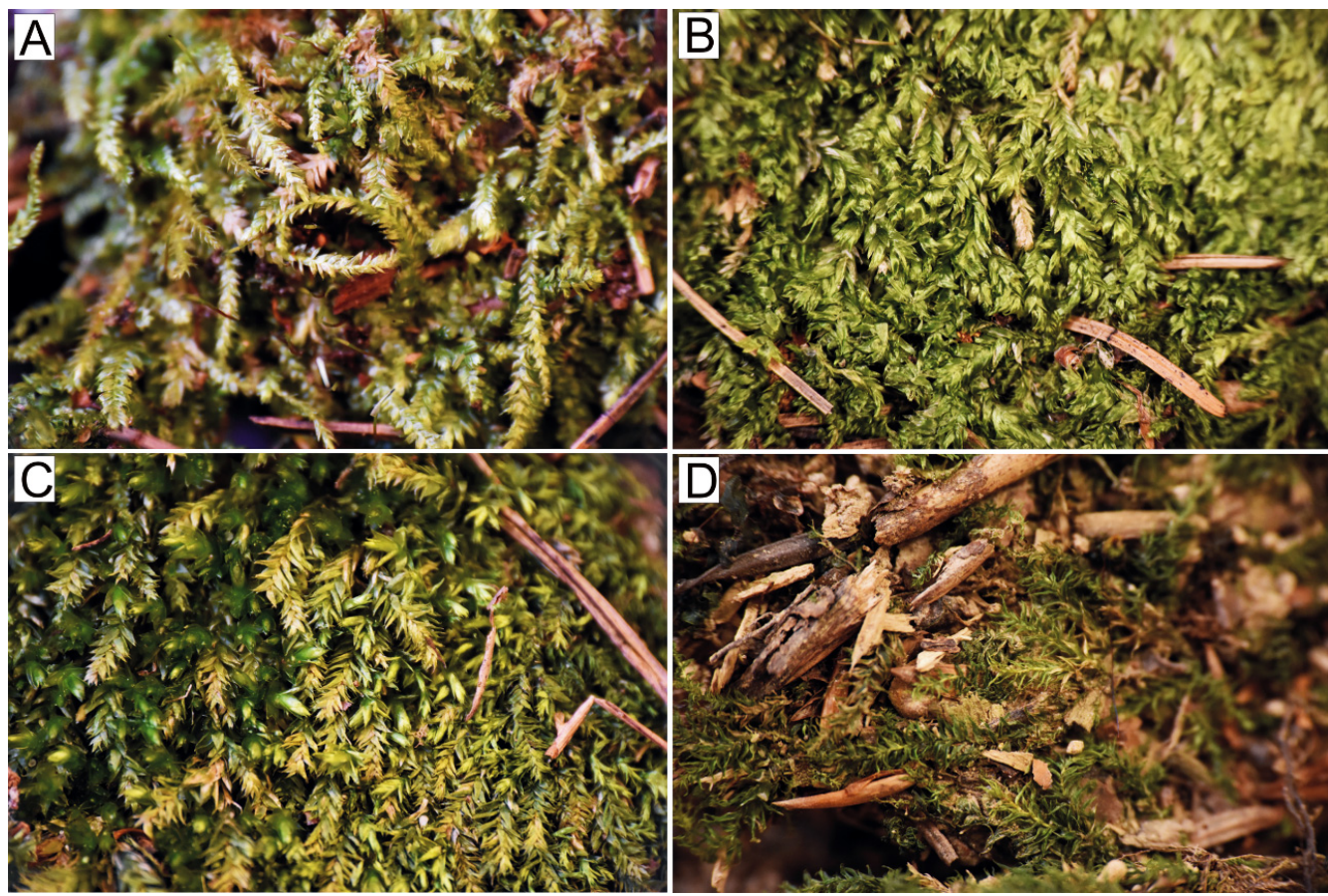

Figure 2. Arrangement of the leaves on the stem. (A). Flattened and glossy leaves of P. curvifolium; (B). Imbricate leaves of $P$. denticulatum; (C). Julaceus leaves of $P$. cavifolium (dark green) and flattened, imbricate leaves of $P$. longisetum (yellowish); (D). Shrunken, dark green leaves of $P$. nemorale (photos by G.J. Wolski, 15 March 2021).
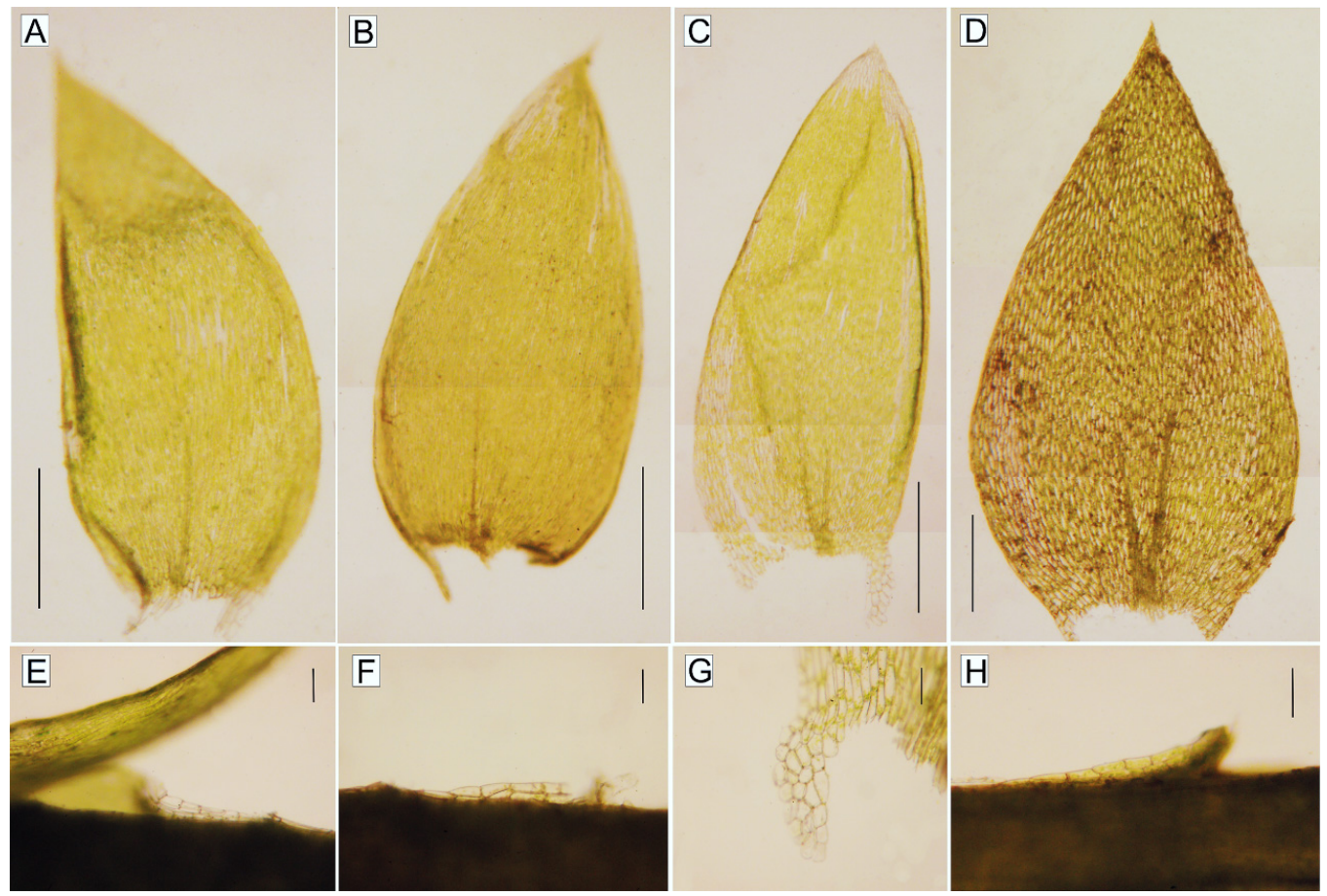

Figure 3. Leaves and decurrent angular cells of selected Plagiothecium species. (A-D). Shape and leaf symmetry: (A). P. curvifolium; (B). P. cavifolium; (C). P. denticulatum; (D). P. nemorale (scale $500 \mu \mathrm{m}) ;(\mathbf{E}-\mathbf{H})$. Shape and dimensions of the decurrent cells: (E). P. curvifolium; (F). P. cavifolium; (G). P. denticulatum; (H). P. nemorale (scale $100 \mu \mathrm{m}$ ) (photos by G.J. Wolski, 15 March 2021). 

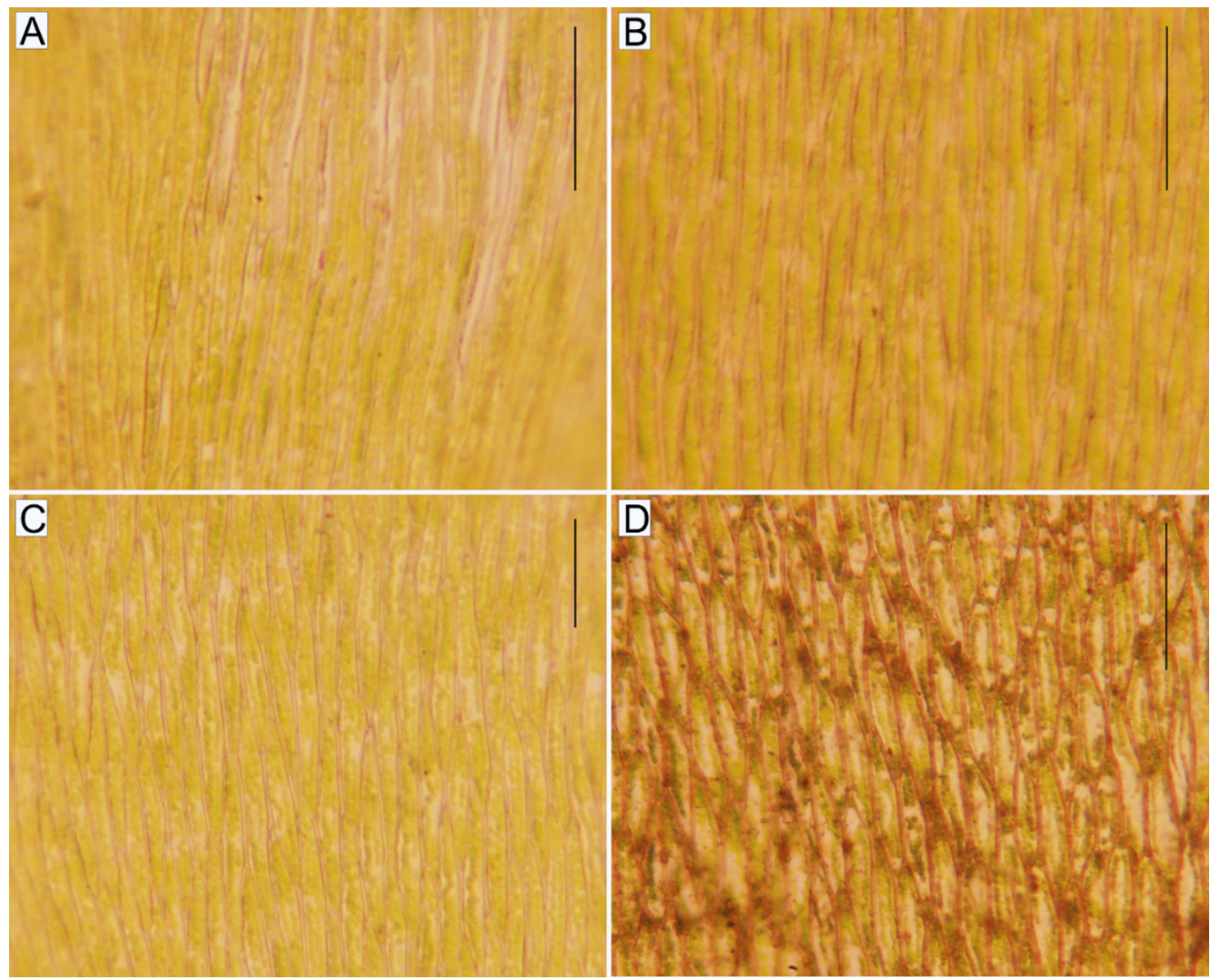

Figure 4. The shape and dimensions of the central part of the leaf cells. (A). P.curvifolium; (B). P. cavifolium; (C). P. denticulatum; (D). P. nemorale (scale $100 \mu \mathrm{m}$ ) (photos by G.J. Wolski, 15 March 2021).

9. Plagiothecium curvifolium fo. julaceum Culm. \& E. Bauer 1915-it is a forgotten taxon, which after being described in 1915 it was not later mentioned as a separate or at least as a synonym in any of the major bryological studies [28,30,32,201-205]. Based on molecular analyses, Wynns [7] recognises it as separate, although the description of the gametophyte characteristics (ramis subjulaceis, foliis imbricatis saepe subhomomallis) indicates features similar to $P$. cavifolium. At this stage, this taxon definitely requires further in-depth research and detailed analysis. Ecology and Distribution. Detailed ecological data and distribution for this taxon are not known exactly and require specific investigation. However, according to Wynns [7], the isotype is found on fir roots near the upper tree line (epiphytic); from Switzerland (Burgfeld in Beatenberg, Canton of Bern).

10. Plagiothecium decoratum J.T. Wynns 2015-the species established by Wynns [23] and described as a julaceous to subcomplanate, slender plant, with concave, ovate, more or less symmetrical, plicate leaves, with recurved margins and a curled, denticulate, hyaline and recurved leaf apex. Ecology. It is listed in epiphytic habitat [7]. Distribution. The species is described as endemic of Bhutan and Nepal [7], present in evergreen forests around $3000 \mathrm{~m}$. According to Wynns et al. [23], this taxon should be searched for elsewhere, as it could reasonably be expected to occur in Sikkim (Northeastern India) — which borders Bhutan in the east and Nepal in the west-and in Yunnan (China).

11. Plagiothecium denticulatum (Hedw.) Schimp 1851-a fairly large plant, green to yellowish green, often glossy (Figure 2); the stem prostrate to ascending, densely foliate; concave, ovate to lanceolate, asymmetrical, acute to acuminate leaves, with recurved margins (Figure 3), an often denticulate apex, and loose cell areolation (Figure 4); median cells linear-rhomboidal; alar regions well-developed, broadly decurrent, composed of large, inflated, round hyaline cells; sporophytes with inclined capsules. These 
features allow this species to be distinguished from others. Ecology. It is considered as a circumboreal species, where it is recorded in epigeic, epilithic, epixylic and epiphytic habitats; more abundant in alpine areas (e.g., [28-30,34,79,194,198,199,206]). Distribution. Apart from Eurasia, it is cited in the literature from North Africa, but considered doubtful by Ros et al. [12]; also the occurrence of this species in subSaharan Africa is considered doubtful by O'Shea [10]. It is also reported from North America (Canada, Greenland, USA) [7,18,25,79,207].

12. Plagiothecium denticulatum var. affine Warnst. 1906-a species with small, flat, asymmetric leaves and well-developed alar regions [7]. Warnstorf [208] stated that P. denticulatum var. affine has a delicate form and resembles $P$. laetum, and that it could be an intermediate form between these species. Intermediate features of this taxon include its delicate structure as well as straight and erect capsules (which is characteristic for all species closely related to P. laetum). Wynns [7] supports this opinion that it may be a hybrid between these two species. Ecology. Warnstorf [208] did not provide details about the ecological preferences of this taxon, however, he indicated that it is a delicate form growing in flat turfs. Distribution. So far, it is reported only from Germany (Bärwalde, between Vietnitz and Nordhausen, Königsberg) [7,208].

13. Plagiothecium denticulatum var. obtusifolium (Turner) Moore 1873-a small, subjulaceous, glossy, soft plant; leaves round, ovate or elliptical, with an obtuse apex, recurved margins and well-developed alar regions. These features distinguish this taxon from other species. Plagiothecium denticulatum var. obtusifolium was treated by some scientists as a synonym of $P$. denticulatum (e.g., $[18,159])$ or considered to be an ecotypic variety, but DNA sequence analyses indicate that $P$. denticulatum var. obtusifolium and P. denticulatum are not the same taxon [7,23]. Ecology. Wynns [7] reported on that $P$. denticulatum var. obtusifolium is restricted to mountains and cliffs, where it is recorded in epigeic, epilithic and epiphytic habitats. Distribution. Outside Eurasia, the species reported from North America (Canada, USA) [7,79].

14. Plagiothecium enerve (Broth.) Q. Zuo 2011 - due to a rather unusual combination of features: small plant with not tumid branches, narrowly lanceolate leaves bordered by hyaline, elongate, thin-walled cells, with an extremely long, often brownish piliferous apex, this plant was first described as Struckia enervis [209]. However, DNA analysis [36] indicates that it belongs to the genus Plagiothecium. Ecology. This species is recorded in epilithic and epiphytic habitats [7]. Distribution. Until now, it is reported from Asia (China and Russia).

15. Plagiothecium euryphyllum (Cardot \& Thér.) Z. Iwats. 1970-a medium-sized to robust, glossy plant, with flattened branches; leaves ovate to elliptical, asymmetric, slightly contorted when dry, broadly acute, more or less undulate; median leaf cell linear, narrow, thin-walled, areolation looks tight. Due to this feature combination, P. euryphyllum is similar and confused with P. neckeroideum, but this species does not have intense iridescent and concave leaves as P. euryphyllum. Ecology. The species is recorded in epigeic, epilithic, epixylic and epiphytic habitats [29,64,79]. Distribution. It is widely spread over Asia (China, Formosa, Japan, Korea and Myanmar) and Eastern Europe (Russia) [7,29,32,72,140].

16. Plagiothecium fallax Cardot \& Thér. 1902-Cardot and Thériot [210] described this species as a robust, light green, shiny plant; leaves broadly ovate-lanceolate, asymmetrical, undulate, with a broad base and wider areolation of thin-walled cells. According to these authors, $P$. fallax is similar to $P$. denticulatum sensu lato, but it can be distinguished from this species by very small alar decurrencies. Ireland [18] and Iwatsuki [29] treated this species as a synonym or variety of P. cavifolium. Ecology. This species is recorded in epigeic habitat. Distribution. Apart from Eurasia (Russian Federation and Japan), it is also reported from North America (USA) and considered to be a typical North Pacific element [7].

17. Plagiothecium japonicum Sakurai 1949—described by Sakurai [211], but Iwatsuki [29] treated this species as a form of $P$. nemorale ( $P$. nemorale fo. japonicum), later even 
as a synonym to this species [33]. Plagiothecium japonicum can be easily recognised by large, broadly ovate, often concave leaves with stiff, extended cells and, as indicated by Wynns [7], it should be treated as a separate species, despite the fact that morphologically and genetically it shows intermediate features between $P$. nemorale and P. cavifolium. Ecology. This species is recorded in epigeic and epilithic habitats. Distribution. Apart from Asia (Japan), it is also reported from North America (USA) and considered a North Pacific element as P. fallax [7].

18. Plagiothecium laetum Schimp. 1851—small plant, pale green to yellowish green, glossy, in loose mats; leaves asymmetrical, narrowly ovate-lanceolate, and narrowlydecurrent, gradually acuminate at apex; median leaf cells linear-rhomboidal; capsules more or less erect. Narrow alar decurrencies and sporophytes with erect capsules easily distinguish this species from closely related ones such as P. curvifolium. A recent taxonomic study of $P$. laetum complex allowed description of a new species, i.e., P. rossicum [26]. Ecology. The species recorded in epigeic, epilithic, epixylic, and epiphytic habitats (e.g., [25,28,30,66,79,171,172,195,212]). Distribution. Apart from Eurasia, this species is also reported from North America (Canada, Greenland, USA) $[7,18,79]$.

19. Plagiothecium laetum var. tenellum (Schimp.) Warnst. 1906-Warnstorf [208] states that this taxon differs from P. laetum by longer, more lanceolate leaves, as well as narrow and long cells. Jedlička [202,203] characterised P. laetum var. tenellum as having small, narrow leaves, very short costae and narrow cells, often with propagules, and small erect capsules. Ecology and Distribution. Warnstorf [208] did not provide data about the ecological preferences of this taxon, therefore detailed ecological data and distribution for this taxon are not known exactly and require specific investigation. However, he indicated that var. tenellum plants are from all locations listed to P. laetum, which include Germany (Crossen, Lübeck, Hamburg and Altmark). The ecological data reported for these locations were: very rare in pine and deciduous forests at the bottom of trees or on forest floor, sometimes also in moors on the edge of old peat holes; often in crevices of lower and higher mountains.

20. Plagiothecium latebricola Wilson ex Schimp. 1851-a small, slender, bright green or yellowish green, glossy plant; leaves erect-spreading, symmetrical, narrowly ovatelanceolate, sometimes complanate, long acuminate, at times shrunken when dry, a margin narrowly recurved, entire or denticulate near the apex; costae very short; median leaf cells linear-rhomboidal; alar regions narrowly decurrent; fusiforme gemmae often present as well as rhizoids at the apex; capsules erect. Because of its small size, colour, short costae, narrow decurrent alar regions and erect capsules, this species can be confused with P. laetum, but even leaf symmetry in the latter helps to distinguish these two species. Ecology. Plagiothecium latebricola is found in swamps, fens, marshes and recorded in epigeic, epilithic, epixylic and epiphytic habitats (e.g., $[21,25,28,30,79,101,199,206,213])$. Distribution. This species has a circumboreal distribution [7], typically found in lowland, shaded locations [21,25]. Apart from Eurasia, it is also reported from North America (Canada, USA) [18,79].

21. Plagiothecium longisetum Lindb. 1872—species described by Lindberg [214], synonymized with P. nemorale by Iwatsuki [29] and treated as such for about 50 years [33], recently resurrected and considered as a separate species [27]. A robust, green to yellow green, plant without metallic lustre (Figure 2); leaves asymmetric to strongly asymmetric, shrunken when dry, ovate to lanceolate; a straight, not denticulate, acute to acuminate apex; leaf cells in regular rows, long and wide, areolation loose; long and burly costae; and very long seta (to $5.5 \mathrm{~cm}$ ). This feature combination allows us to easily distinguish this species from $P$. nemorale and other closely related species. Ecology. It is recorded in epigeic, epilithic, epixylic and epiphytic habitats [27]. Distribution. Apart from Eurasia, this species is also reported from North America (Canada, USA) [191].

22. Plagiothecium neckeroideum Schimp. 1851-a robust, green to yellowish green, strongly complanate plant; leaves domorphic, triangular, asymmetrical, ovate, undulate, con- 
cave, and a serrulate apex; median leaf cells linear-rhomboidal, narrow; alar decurrencies hyaline, thin-walled and well-developed. Apex cells are nematogenous, leaves often with differentiated apical cells, often seen as a longitudinal brown stripe at the leaf apex. Ecology. It is noted in epigeic, epilithic, epixylic and epiphytic habitats (e.g., [29,34,66,79]). Distribution. Wynns [7] reported P. neckeroideum from East and Southeastern Asia and in the Himalayas, from Europe (in the Alps). Deng-ke and Ireland [79] also gives this species from North America.

23. Plagiothecium neckeroideum fo. exile J.T. Wynns 2015-a taxon described by Wynns [23] as a small plant, with slender stems and branches, reddish stems; concave, not undulate, acuminate leaves; leaf cell areolation composed of short and narrow cells; decurrencies with enlarged, hyaline alar cells. Ecology. Reported from Quercus semecarpifolia forest, on tree trunk (epiphytic) [23]. Distribution. So far, the taxon is known only from Nepal.

24. Plagiothecium neckeroideum var. javense M. Fleisch. 1920-Fleischer [215] describes this taxon as a large, light green plant, with pale, symmetric, concave, undulate, long acuminate leaves, a denticulate apex, short costae, thin-walled leaf cells, enlarged in the basal area, with a vertical stripe of nematogenous cells at the apex. Ecology. This taxon was recorded in epigeic and epilithic habitats. Distribution. Apart from Southeast Asia (Indonesia, Philippines), it is also reported from Papua New Guinea [216] and from East Africa (Ethiopia) [10].

25. Plagiothecium neckeroideum var. myurum Molendo 1875-smaller than P. neckeroideum var. javense, other features that make it different from closely related species are that it is a julaceous plant, with strongly concave, not undulate leaves [7,217]. Ecology. It is a montane taxon, recorded in epigeic, epilithic, epixylic and epiphytic habitats [7]. Distribution. Reported from Sino-Himalayan region (Bhutan, China, India, Nepal) [23].

26. Plagiothecium neckeroideum var. niitakayamae (Toyama) Z. Iwats. 1970—a big, light green, julaceous plant, with symmetrical, plicate leaves; this variety differs from the species by more julaceous, symmetric, undulate leaves. Ecology. This taxon was recorded in epigeic, epilithic and epiphytic habitats [7,29,79]. Distribution. Recorded from East Asia (China, Japan, Taiwan) and Southeast Asia (Philippines).

27. Plagiothecium neckeroideum fo. paroum J.T. Wynns 2015-a form proposed by Wynns [7], who describes it as a small, pale green, crispate when dry, with flat or undulate, very concave, cordate, short, broad and very asymmetrical leaves, with an acuminate, acute and denticulate apex, often with rhizoids; leaf cells narrow; this form is similar to $P$. subglaucum, but in $P$. neckeroideum fo. parvum the leaves are broader. Ecology. This taxon was recorded in epigeic habitats [7]. Distribution. So far, it is known only from Taiwan (East Asia).

28. Plagiothecium nemorale (Mitt.) A. Jaeger 1878 - this species has been too widely described in the last few decades, a taxonomic review of $P$. nemorale sensu lato indicates that it is actually three separate species: $P$. nemorale sensu stricto, P. longisetum and P. angusticellum [27]. A medium to large, green to dark green plant, shrunken when dry (Figure 2) and without metallic luster; leaves ovate, symmetric (Figure 3); acute to acuminate, straight; a denticulate apex; leaf cells short and wide, loose areolation, symmetric, in regular rows (Figure 4). This feature combination makes it very easy to distinguish this species from other closely related species. Ecology. The species is recorded in epigeic, epilithic, epixylic, and epiphytic habitats (e.g., [25,27-29,34,66,79,141,194,199,200,218]). Distribution. The species is quite common in Eurasia [27]. It is also reported by Ros et al. [12,47] from North Africa (Algeria, Tunisia) and reported from North America (Canada, USA) [27,191].

29. Plagiothecium noricum Molendo ex Limpr. 1897-flaccid, not undulate, very concave leaves, with expended cell aerolation, denticulate; rhizoids at the apex. Ecology. Wynns [7] describes P. noricum as a still little-known Alpine species, where are listed 
from epigeic habitat. Distribution. Reported from the Southern part of Central Europe (Austria) and Southeast Asia (Myanmar).

30. Plagiothecium obtusissimum Broth. 1921-a yellowish green to pale green, glossy plant with metallic luster; leaves ovate, rounded-obtuse at the apex, asymmetrical, slightly concave, the margin often erect at one side; leaves with suddenly differentiated alars, composed by hyaline inflated cells; median cells linear-flexuose, very narrow and long, thin-walled. Iwatsuki [29] considered P. obtusissimum to be closely related to P. euryphyllum, due to similar alar cells, leaf cells and setae. Additionally, it is easily distinguished from this species by the plant size and shape of leaf apex. DNA analysis confirms the observations about the close relationship between these species [36]. Ecology. Plagiothecium obtusissimum is recorded in epigeic, epilithic, epixylic and epiphytic habitats (e.g., [29,34]). Distribution. Noguchi [34] considered this species to be endemic to Japan; however, it is later reported from Russia (e.g., [32]).

31. Plagiothecium piliferum (Sw.) Schimp. 1851-a small, slender, pale green and glossy plant; leaves ovate, deeply concave, almost symmetrical, abruptly contracted to a piliferous, sometimes flexuose apex, with recurved margins; median leaves linearrhomboidal, very narrow; alar regions narrowly decurrent. Ecology. Plagiothecium piliferum is recorded in epigeic, epilithic, and epixylic habitats (e.g., $[25,28,30,79])$. Distribution. Apart from Eurasia, this species is also reported from North America (Canada, Greenland, USA) in low to moderate elevations [7,21,30,79].

32. Plagiothecium platyphyllum Mönk. 1927-a medium-sized to robust, green, glossy plant; leaves ovate-lanceolate, asymmetrical, complanate, facid, undulate; median leafcells linear-romboidal, apical cells often bearing rhizoids; alar cells hyaline to pale green. According to Ireland [18], it is an autopolyploid of $P$. denticulatum, while a DNA study [219] suggested that $P$. denticulatum var. obtusifolium is a haploid of P. platyphyllum. Ecology. Plagiothecium platyphyllum is recorded in epigeic, epilithic, epixylic, and epiphytic habitats (e.g., [25,28,30,79,128,194]). Distribution. Apart from Eurasia, it is also reported from North America (Canada, USA) $[7,23]$.

33. Plagiothecium rhizophyllum Sakuri 1932-described by Sakurai [220] as a small species, with not undulate, loose cell areolation and rhizoids at the apex. Iwatsuki $[29,221]$ and researchers after him (e.g., [33]) consider it as a synonym of $P$. nemorale, but Wynns [7] treats P. rhizophyllum as a separate species. Ecology. It is recorded in epigeic habitat [7]. Distribution. So far, the species reported only from East Asia (China).

34. Plagiothecium rossicum Ignatov \& Ignatova 2019-described on the basis of DNA analyses of the P. laetum complex by Ignatova et al. [26]. A small plant with distinctly complanate foliage; leaves asymmetrical, ovate-lanceolate, a narrowly acute to short acuminate apex, margins flat, entire or minutely denticulate at the apex; leaf cells long and very narrow; straight and erect capsules. In terms of many features, this species is similar to $P$. laetum, but a flat margin and strongly asymmetric leaves are very useful in distinguishing $P$. rossicum from this species. Many features allow this species to be distinguished also from $P$. svalbardense, including for example: A flat leaf margin, narrow cells, narrowly acute to short acuminate apex which characterise P. rossicum. Ecology. So far, this species has been recorded in epigeic, epilithic, epixylic and epiphytic habitats [26]. Distribution. The species in common in boreal and hemiboreal forests of Russia, one position is also given from Poland [26].

35. Plagiothecium ruthei Limpr. 1897-a medium-sized to large plant; leaves strongly complanate on the stem, transversely undulate when moist, sometimes shrunken when dry, flaccid, acuminate, strongly asymmetrical, on side almost straight, leaves with narrowly recurved margins and well-developed alar regions. These features distinguish this species from other closely related species. It is recognised as a separate species throughout Eurasia, despite the fact that DNA data places this plant closer to $P$. denticulatum, even closer than P. denticulatum var. obtusifolium $[7,23]$. Ecology. Plagiothecium ruthei is typical of wetlands species, recorded in epigeic, epixylic, and epiphytic habitats (e.g., $[25,30,194])$. Distribution. Apart from Eurasia, this species is 
also reported from North Africa but considered doubtful by Ros et al. [12]; and from North America (Canada, USA) [7].

36. Plagiothecium ruthei var. rupincola Limp. 1897-Limpricht [222] described this taxon as similar to $P$. ruthei due to the size and cell areolation, but different due to closer foliage; symmetrical leaves, lacking recurved margin. Ecology. Limpricht [222] described it as an epilithic, alpine taxon. Distribution. According to the protologue and Wynns [7], this taxon is reported from Central, Northern and Western Europe (Asutria, Czech Republic, France, Germany, Norway and Sweden).

37. Plagiothecium subglaucum Thwaites \& Mitt. 1873-Mitten [223] described this species as a plant with ovate, flat leaves, with an acute to acuminate apex. Plagiothecium subglaucum is similar to and can be confused with P. neckeroideum. Both species require further in-depth research [7]. Ecology. It is recorded in epigeic and epiphytic habitats. Distribution. So far, known only from Sri Lanka (South Asia) and Myanmar (Southeast Asia).

38. Plagiothecium succulentum (Wilson) Lindb. 1865-a robust, yellowish green to golden green, very glossy plant, leaves symmetric, lanceolate, not shrunken when dry, with an entire apex; median leaf cells very long. Plagiothecium succulentum differs from P. nemorale by lanceolate leaves, longer cells and a smooth apex; and from $P$. longisetum by lanceolate, symmetrical leaves; from other closely related species (e.g., $P$. angusticellum), it is very easy to distinguish, for example, by leaf symmetries and loose cells areolation [27]. Wynns [7] considered P. succulentum as problematic and described this species as polyphyletic or intermediate between $P$. nemorale and P. cavifolium. Plagiothecium succulentum in some countries is indicated as doubtful (Table 2, Figure S4). In our opinion, the relationship between these above-mentioned species requires a detailed analysis. Ecology. Plagiothecium succulentum is recorded in epigeic, epilithic, and epiphytic habitats (e.g., [25,28,30,62,79,194]). Distribution. Apart from Eurasia, this species is also reported from North Africa (a single record from Tunisia) [47]; and from North America (Canada, USA) [191].

39. Plagiothecium succulentum fo. propaguliferum E. Bauer 1902-a very dark, small plant, with shrunken leaves when dry. These are the features that distinguish this form from P. succulentum. Wynns [7] commented that this taxon can be frequently found in herbaria under the name P. succulentum. Ecology. This taxon is recorded in epilithic and epiphytic habitats [7]. Distribution. Currently, P. succulentum fo. propaguliferum is recorded in Western, Northern and Western Europe [7], and from North America (Canada, USA) [7,191].

40. Plagiothecium svalbardense Frisvoll 1996-a small, growing erect plant, crispy when dry; leaves small, weakly undulate, concave, symmetrical to slightly asymmetrical, short, ovate, gradually tapered to the apex; margins narrowly recurved, entire or minutely denticulate at the apex; a subpiliferous apex; capsules straight and erect. Plagiothecium svalbardense is different from P. laetum by leaf shape and apex shape, the described species is also similar to $P$. piliferum due to its apex, but the latter has narrower leaf cells and a longer apex. The shape and arrangement of capsules is similar to P. laetum and P. berggrenianum but different from P. curvifolium. Ecology. Wynns [7] described $P$. svalbardense as an arctic species, where it is recorded in epilithic and epixylic habitats [26]. Distribution. Apart from Eurasia (Russia, Svalbard, Sweden), this species is also reported from North America (Greenland) [7].

41. Plagiothecium undulatum (Hedw.) Schimp. 1851-a large white to pale green, dull plant; leaves large, imbricate, crispate, slightly asymmetric, acute and serrulate at the apex; rhizoids occur at the leaf insertion; leaf cells with papillae on abixal surfaces. These mentioned features led Ireland [224] to create for this species (as well as P. draytonii (Sull.) E.B. Bartram) a separate genus-Buckiella Ireland. Plagiothecium undulatum is similar to P. neckeroideum, but it differs by size and colour of the plant as well as longer and broader median leaf cells. Ecology. Plagiothecium undulatum was recorded in 
epigeic, epilithic, and epiphytic habitats (e.g., $[25,28,30,79,197])$. Distribution. Apart from Eurasia, this species is also reported from North America (Canada, USA) [7,18,79].

\section{Materials and Methods}

\subsection{The Area of the Checklist}

The present study covers Eurasia (Figure 5), which comprises all of Europe and Asia, excluding Papua New Guinea. It also includes archipelagos of Northern Macaronesia, i.e., the Azores, Madeira and the Canary Islands but excl. the Cape Verde (Cabo Verde) archipelago. From the political and administrative perspective, Eurasia includes Europe and Asia (excl. the Sinai Peninsula, which is usually linked to Africa; being part of Egypt, though geographically it is located in Asia; anyhow Plagiothecium had never been reported from Sinai, see [225]). The area covered by the present checklist includes 107 countries of Europe and Asia, some well-separated islands, and archipelagos. According to the "World Geographical Scheme for Recording Plant Distributions" by Brummitt [226], it includes:

- $\quad$ Europe (Northern, Middle, Southwestern, Southeastern, and Eastern Europe);

- Asia-Temperate (Siberia, Russian Far East, Middle Asia, Caucasus (excl. partially recognised countries such as Abkhazia), Western Asia, the Arabian Peninsula, China, Mongolia, and Eastern Asia); and

- Asia-Tropical (Indian Subcontinent, Indo-China, Malaysia, but excl. Papuasia).

A list of Eurasian countries and islands, along with their abbreviations used throughout the text, is presented in alphabetical order in Table 1. Abbreviations of countries and regions follow TDWG geographical codes [226] with some exceptions. The resulting distribution maps of the accepted taxa are provided as Supplementary Materials (Figures S1-S4).

\subsection{Data Collection and Presentation}

This study is based primarily on information garnered from the literature available to the authors up to the end of June 2020. More than two hundred publications have been consulted and analysed, including important regional and local floras, checklists, floristic reports, various studies and revisions of the family Plagiotheciaceae and the genus Plagiothecium in all European and Asian biogeographic regions or countries. Information on species names, occurrence, distribution, ecology and taxonomy have been compiled from these publications, which covered almost all the work published on Plagiothecium over a period of more than 70 years by several authors and written in different languages. In addition, the authors' own observations and online databases/checklists available on bryophytes of several regions/countries under consideration were used. All synonyms appearing in the collected literature were compiled for each taxon (see Appendix A).

The Eurasian regions are arranged alphabetically and a regional distribution is reported for each individual taxon. Data are presented in tabular format (Table 2) and distribution maps are provided for all reported taxa (see Figures S1-S4). Sections are arranged phylogenetically. Within sections, taxa are arranged alphabetically, first by the generic name, then by the specific epithet and infraspecific name-without any consideration of their phylogenetic relationships. Entries within each section follow the order: Taxon name, authority, publication data (pertaining to taxon first valid publication), then followed by distribution data (literature references for each country from which the taxon is reported), see Appendix B. Abbreviations of countries are printed in boldface. Author abbreviations follow [227].

The frequency of occurrence of Eurasian species has been presented on a five-point scale: very rare species (from $1 \%$ to $5 \%$ of all countries/islands in which a given taxon occurred), rare (6-10\%), frequent (11-25\%), very frequent (from $26-50 \%$ ) and common (more than $50 \%$ of all countries/islands in which the taxon occurs). 


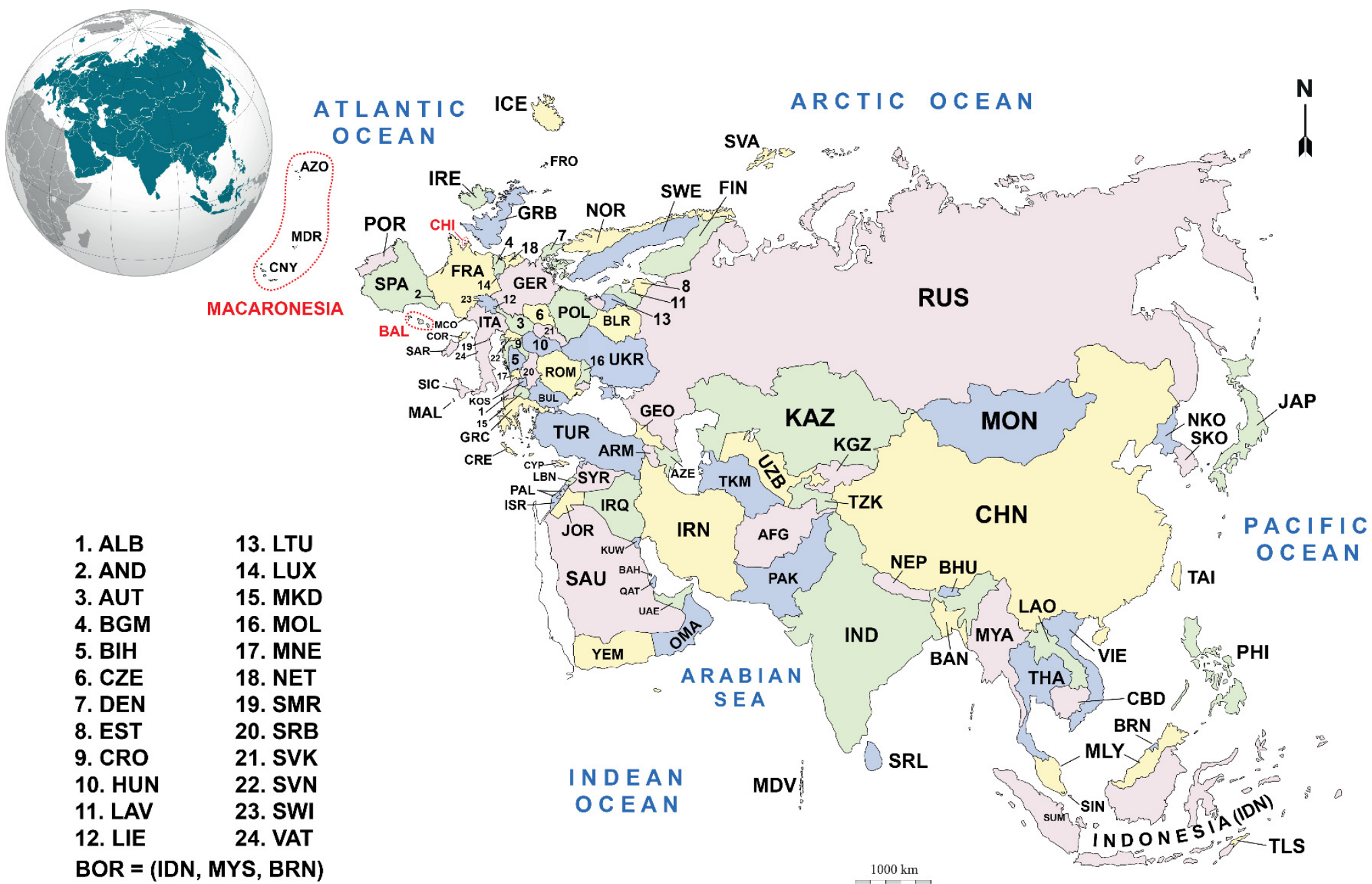

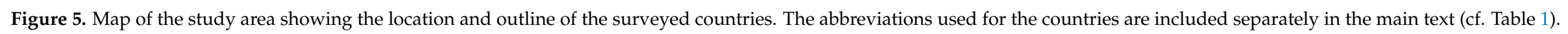




\subsection{Nomenclature and Taxonomy}

The revised sectional classification of Plagiothecium established by Wynns [7] based on phylogenetic analysis of DNA sequence data, is adopted in the present study with a few exceptions. Consequently, the following taxa have been excluded from the present study: P. handelii Broth. and P. paleaceum (Mitt.) A. Jaeger, which after Wynns and Schröck [37] were sanctioned as Ortholimnobium handelii (Broth.) C. Schröck \& J.T. Wynns and O. paleaceum (Mitt.) C. Schröck \& J.T. Wynns, respectively. Whereas taxa considered in this study and not included in [7] are: P. rossicum Ignatov \& Ignatova, which was established by Ignatova et al. [26] based on phylogenetic analysis of the P. laetum complex; as well as P. angusticellum G.J. Wolski \& P. Nowicka-Krawczyk and P. longisetum Lindb., which were erected and resurrected, respectively, based on application of polyphasic approach to investigate the P. nemorale sensu lato [27].

\subsection{Conspectus of Classification of Plagiothecium}

All species are classified into the sections proposed by Wynns [7] and Wynns et al. [23], while for species that were described/accepted after 2015, we suggested that they can be provisionally classified under Plagiothecium sect. Leptophyllum (for P. rossicum) and Plagiothecium sect. Orthophyllum (for P. angusticellum and P. longisetum) and so this was adopted and included below (based on the literature cited in the two sections above).

All the following sections are represented in Eurasia.

Note. Included taxa listed here are as provided in $[7,23,26,27,37]$, infraspecific taxa are not included.

Plagiotheciaceae M.Fleisch., Nova Guinea 8: 748. 1912;

Hypnaceae subfam. Plagiothecioideae Brotherus in Engler and Prantl, Nat. Pflanzenfam. 1(3): 1021, 1078. 1908, "Plagiothecieae". Type. Plagiothecium Schimper.

Plagiothecium Schimper in Bruch, Schimper and Gümbel, Bryol. Eur. 5:179. 1851 三 Stereodon (Bridel) Mitten sect. Plagiothecium (Schimper) Mitten, J. Linn. Soc., Bot. 4: 88. 1859. Type. Plagiothecium denticulatum (Hedwig) Schimper in Bruch, Schimper and Gümbel, Bryol. Eur.

1. Plagiothecium Schimp. sect. Plagiothecium $\equiv$ Plagiothecium sect. Falciphyllum Jedl., nom. illeg. Spisy Vydá. Př́r. Fak. Masarykovy Univ. 308: 23. 1948. = Plagiothecium sect. Rostriphyllum Jedl. Spisy Vydá. Přír. Fak. Masarykovy Univ. 308: 32. 1948.

This section consists of 11 species: P. brasiliense (Hampe) A. Jaeger, P. cochleatum Dixon, P. conostegium Herzog, P. denticulatum (Hedw.) Schimp., P. lamprostachys (Hampe) A. Jaeger, P. membranosulum Müll. Hal., P. nitens Dixon, P. ovalifolium Cardot, P. platyphyllum Mönk., P. ruthei Limpr., P. selaginelloides Müll. Hal.

2. Plagiothecium sect. Orthophyllum Jedl. Spisy Vydá. Přír. Fak. Masarykovy Univ. 308: 35. 1948.

This section consists of 7 species: P. angusticellum G.J. Wolski \& P. Nowicka-Krawczyk, P. cavifolium (Brid.) Z. Iwats., P. japonicum Sakurai, P. longisetum Lindb., P. nemorale (Mitt.) A. Jaeger, P. rhizophyllum Sakurai, P. succulentum (Wilson) Lindb.

3. Plagiothecium sect. Leptophyllum Jedl. Spisy Vydá. Přír. Fak. Masarykovy Univ. 308: 23. 1948. = Plagiothecium sect. Philoscia (Berk.) Ochyra. Biodiversity of Poland 3: 177. 2003. $\equiv$ Philoscia Berk. Handbook of British Mosses 49, 146. 1863.

This section consists of 12 species: P. andinum (Hampe) A. Jaeger, P. berggrenianum Frisvoll, P. curvifolium Schlieph. ex Limpr, P. funale J.T. Wynns, P. laetum Schimp., P. latebricola Wilson ex Schimp., P. lucidum (Hook. f. and Wilson) Paris, P. mollicaule R.S. Williams, P. pacificum J.T. Wynns, P. rhizolucidum J.T. Wynns, P. rossicum Ignatov \& Ignatova, P. svalbardense Frisvoll. 
4. Plagiothecium sect. Pseudo-Neckera (Kindb.) J.T. Wynns. Cladistics 34: 469-501. 2018. $\equiv$ Plagiothecium subgen. Pseudo-Neckera Kindb. European and North American Bryineae (Mosses) 1: 69. 1897.

This section consists of 4 species: P. decoratum J.T. Wynns, P. neckeroideum Schimp., P. noricum Molendo ex Limpr., P. subglaucum Thwaites \& Mitt.

5. Plagiothecium sect. Lycambium Jedl. 1948. Spisy Vydá. Přír. Fak. Masarykovy Univ. 308: 10. 1948. 三 Buckiella Ireland. Novon 11(1): 55. 2001.

This section consists of 3 species: P. draytonii (Sull.) E.B. Bartram, P. fallax Cardot \& Thér., P. undulatum (Hedw.) Schimp.

6. Plagiothecium sect. Saviczia (Abramova \& I.I. Abramov) Z. Iwats. J. Hattori Bot. Lab. 33: 341. 1970. 三 Saviczia Abramova \& I.I. Abramov. Novosti Sist. Nizsh.Rast. 1966: 298. 1966.

This section consists of 2 species: P. euryphyllum (Cardot \& Thér.) Z. Iwats., P. obtusissimum Broth.

7. Plagiothecium sect. Struckia (Müll. Hal.) J.T. Wynns. Cladistics 34: 469-501. 2018. $\equiv$ Struckia Müll. Hal. Arch. Vereins Freunde Naturgesch. Mecklenburg 47: 129. 1893.

This section consists of 2 species: P. argentatum (Mitt.) Q. Zuo, P. enerve (Broth.) Q. Zuo.

8. Plagiothecium sect. Rectithecium (Hedenäs \& Huttunen) J.T. Wynns. Cladistics 34: 469-501. 2018. E Rectithecium Hedenäs \& Huttunen. Bot. J. Linn. Soc. 171(2): 344. 2013.

This section consists of one species: P. piliferum (Sw.) Schimp.

Note: All sections proposed by Wynns [7] and Wynns et al. [23] are represented in Eurasia except Plagiothecium sect. Ortholimnobium. It should be noted, however, that this section includes the two species $P$. handelii and $P$. paleaceum, which are not considered in the present study in light of the new evidence published by Wynns and Schröck [37], as explained above.

Supplementary Materials: The following are available online at https:/ / www.mdpi.com/article/10.3 390/plants10050868/s1, Figure S1: Maps showing the distribution of Plagiothecium taxa in Eurasia per country/region. A. The distribution of $P$. argentatum, $P$. berggrenianum, $P$. cochleatum, $P$. conostegium, P. decoratum, P. enerve, P. euryphyllum, P. fallax, P. japonicum, P. noricum, P. obtusissimum, P. rhizophyllum, $P$. rossicum, $P$. subglaucum and $P$. svalbardense. B. The distribution of $P$. cavifolium and $P$. cavifolium var. orthocladium, Figure S2: Maps showing the distribution of Plagiothecium taxa per country/region. A. The distribution of P. curvifolium, P. curvifolium fo. julaceum and P. undulatum. B. The distribution of $P$. denticulatum, P. denticulatum var. affine and P. denticulatum var. obtusifolium, Figure S3: Maps showing the distribution of Plagiothecium taxa per country/region. A. The distribution of P. laetum, P. laetum var. tenellum and P. latebricola. B. The distribution of P. neckeroideum, P. neckeroideum var. javense, P. neckeroideum var. myurum, $P$. neckeroideum var. niitakayamae, $P$. neckeroideum fo. exile and P. neckeroideum fo. paroum, Figure S4: Maps showing the distribution of Plagiothecium taxa per country/region. A. The distribution of $P$. angusticellum, $P$. longisetum, $P$. nemorale, $P$. piliferum and P. platyphyllum. B. The distribution of P. ruthei, P. ruthei var. rupicola, P. succulentum and P. succulentum fo. propaguliferum.

Author Contributions: Conceptualization, G.J.W., S.N. and W.E.; investigation, G.J.W., S.N., A.C., D.B. and W.E.; writing—original draft preparation, G.J.W., S.N., A.C., D.B. and W.E.; writing-review and editing, G.J.W., S.N. and W.E.; visualization, G.J.W., S.N. and W.E.; supervision, G.J.W. All authors have read and agreed to the published version of the manuscript.

Funding: This research received no external funding.

Institutional Review Board Statement: Not applicable.

Informed Consent Statement: Not applicable.

Data Availability Statement: No new data were created or analysed in this study. Data sharing is not applicable to this article. 
Acknowledgments: We are grateful to Anders Hagborg from Field Museum of Natural History, Chicago, U.S.A, and Samantha D 'Acunto reference librarian from LuEsther T. Mertz Library, New York Botanical Garden, New York, U.S.A. We are also deeply indebted to all scholars who have shared their own research or contributed useful publications and/or comments and to those who have contributed directly or indirectly to this checklist. Thanks are also due to the academic editor and three anonymous reviewers for their constructive comments and suggestions which improved the manuscript a great deal.

Conflicts of Interest: The authors declare no conflict of interest.

\section{Appendix A}

List of synonyms and names used in the studied area literature, with reference to the currently accepted names (in bold).

Buckiella undulata (Hedw.) Ireland = Plagiothecium undulatum

Cephalocladium enerve (Broth.) Abramova \& I. I. Abramov = Plagiothecium enerve

Fissidens denticulatus Baumg. = Plagiothecium denticulatum

Fobronia enervis Broth. = Plagiothecium enerve

Hypnum argentatum Mitt. = Plagiothecium argentatum

Hypnum cavifolius Brid. = Plagiothecium cavifolium

Hypnum denticulatum auct. non Hedw. = Plagiothecium cavifolium

Hypnum denticulatum L. ex Hedw. = Plagiothecium denticulatum

Hypnum denticulatum var. densum (Schimp.) Lesq. \& James = Plagiothecium denticulatum

Hypnum denticulatum var. donnianum (Sm.) Hook. = Plagiothecium denticulatum

Hypnum denticulatum var. laetum (Schimp.) Lindb. = Plagiothecium laetum

Hypnum denticulatum var. majus Boulay = Plagiothecium denticulatum

Hypnum denticulatum var. obtusifolium Turner = Plagiothecium denticulatum var. obtusifolium

Hypnum denticulatum var. piliferum (Hartm.) Wahlenb. = Plagiothecium piliferum

Hypnum denticulatum var. sublaetum Lind. = Plagiothecium laetum

Hypnum denticulatum var. succulentum Wilson = Plagiothecium succulentum

Hypnum denticulatum var. tenellum (Schimp.) Husn. = Plagiothecium laetum

Hypnum lamprostachys Hamp. = Plagiothecium denticulatum

Hypnum letabricola (Schimp.) Hobk. = Plagiothecium latebricola

Hypnum obtusifolium (Turner) Brid. = Plagiothecium denticulatum var. obtusifolium

Hypnum orthocarpum Aongstr. = Plagiothecium piliferum

Hypnum roeseanum Hampe = Plagiothecium curvifolium

Hypnum silvaticum Hedw. ex. Lindb. nom. inval. in synon. err. orthogr. pro. Hypnum

sylvaticum Brid. = Plagiothecium denticulatum

Hypnum succulentum Wilson = Plagiothecium succulentum

Hypnum sullivantiae Sull. \& Lesq. = Plagiothecium cavifolium

Hypnum sylvaticum auct. non Brid. = Plagiothecium nemorale

Hypnum sylvaticum Brid. = Plagiothecium denticulatum

Hypnum trichophorum Spruce = Plagiothecium piliferum

Hypnum trichophorum var. brevipile (Schimp.) Lindb. = Plagiothecium piliferum

Hypnum undulatum Hedw. = Plagiothecium undulatum

Isopterygiopsis piliferum (Hartm.) Loeske = Plagiothecium piliferum

Isopterygium euryphyllum Cardot \& Thér. = Plagiothecium eurphyllum

Isopterygium latebricola (Schimp.) Delogne = Plagiothecium latebricola

Isopterygium piliferum (Sw.) Loeske = Plagiothecium piliferum

Leskea laeta $($ Schimp.) Bergger. = Plagiothecium laetum

Leskea latebricola (Schimp.) Wilson = Plagiothecium latebricola

Leskea pilifera Sw. ex. Hartm. = Plagiothecium piliferum

Plagiothcium nemorale fo. japonicum (Sakurai) Z. Iwats. 三 Plagiothecium japonicum

Plagiotheciella latebricola (Schimp.) M. Fleisch. = Plagiothecium latebricola

Plagiotheciella pilifera (Sw.) M. Fleisch. = Plagiothecium piliferum

Plagiothecium annotinum Stirt. ex Dixon nom. inval. = Plagiothecium denticulatum var. obtusifolium

Plagiothecium apiculatum Sakurai = Plagiothecium cavifolium

Plagiothecium auritum (Kern.) Jedl. = Plagiothecium ruthei

Plagiothecium cavifolium fo. otii (Sakurai) Z. Iwats. = Plagiothecium cavifolium

Plagiothecium cavifolium var. fallax (Cardot \& Thér.) Z. Iwats. = Plagiothecium fallax

Plagiothecium chuzensii Iisiba ex Sakurai = Plagiothecium platyphyllum

Plagiothecium cochlearifolimus Dixon = Plagiothcium cavifolium

Plagiothecium crudum Sakurai = Plagiothcium cavifolium

Plagiothecium denticulatum fo. laticuspis F. Koppe = Plagiothecium denticulatum var. obtusifolium

Plagiothecium denticulatum subsp. aptychus Spruce = Plagiothecium curvifolium

Plagiothecium denticulatum subsp. donnianum (Sm.) Giacom. = Plagiothecium denticulatum

Plagiothecium denticulatum subsp. laetum (Schimp.) Kindb. = Plagiothecium laetum

Plagiothecium denticulatum subsp. ruthei (Limpr.) Kindb. = Plagiothecium ruthei

Plagiothecium denticulatum subsp. sulcatum Spruc. = Plagiothecium denticulatum

Plagiothecium denticulatum var. aptychus Lees in Dix. = Plagiothecium curvifolium

Plagiothecium denticulatum var. cryptarum Renauld \& Hérib. = Plagiothecium cavifolium

Plagiothecium denticulatum var. curvifolium (Limpr.) Meylan = Plagiothecium curvifolium

Plagiothecium denticulatum var. donnianum (Sm.) Lindb. ex Weim. = Plagiothecium denticulatum

Plagiothecium denticulatum var. donnii Lindb. = Plagiothecium denticulatum var. obtusifolium

Plagiothecium denticulatum var. eciliatum Pfeff. = Plagiothecium laetum

Plagiothecium denticulatum var. gravetii (Piré) Husn. = Plagiothecium laetum

Plagiothecium denticulatum var. imbricatum (Boulay) Meyl. = Plagiothecium denticulatum 
Plagiothecium denticulatum var. laetum (Schimp.) Lindb. = Plagiothecium laetum

Plagiothecium denticulatum var. laxum Schimp. = Plagiothecium denticulatum

Plagiothecium denticulatum var. majus (Boulay) Delogne = Plagiothecium denticulatum

Plagiothecium denticulatum var. microcarpum Renauld \& Cardot = Plagiothecium curvifolium

Plagiothecium denticulatum var. myurum Schimp. = Plagiothecium cavifolium

Plagiothecium denticulatum var. nervosum (Renauld) Mém. = Plagiothecium platyphyllum

Plagiothecium denticulatum var. orthocladium (Schimp.) Hérib. = Plagiothecium cavifolium var. orthocladium

Plagiothecium denticulatum var. orthocladum Warnst. = Plagiothecium denticulatum

Plagiothecium denticulatum var. phyllorhizans Schiffn = Plagiothecium denticulatum

Plagiothecium denticulatum var. podperae Jedl. = Plagiothecium cavifolium

Plagiothecium denticulatum var. propaguliferum (R. Ruthe ex Limpr.) Warnst. = Plagiothecium denticulatum

Plagiothecium denticulatum var. recurvum Warnst. = Plagiothecium curvifolium

Plagiothecium denticulatum var. roeseanum (Schimp.) Hérib. = Plagiothecium cavifolium

Plagiothecium denticulatum var. ruthei (Limpr.) Riehm. = Plagiothecium ruthei

Plagiothecium denticulatum var. secundum Lindb. = Plagiothecium laetum

Plagiothecium denticulatum var. sublaetum (Lindb.) Breidl. = Plagiothecium laetum

Plagiothecium denticulatum var. succulentum (Wilson) Dixon = Plagiothecium succulentum

Plagiothecium denticulatum var. sullivantiae (Sull.) Dix. = Plagiothecium cavifolium

Plagiothecium denticulatum var. tenellum Schimp. = Plagiothecium laetum var. tenellum

Plagiothecium denticulatum var. undulatum R. Ruthe $\equiv$ Plagiothecium ruthei

Plagiothecium dimorphophyllum Sakurai = Plagiothecium euryphyllum

Plagiothecium doii Sakurai = Plagiothecium euryphllum

Plagiothecium donnianum (Sm.) Mitt. = Plagiothecium denticulatum var. obtusifolium

Plagiothecium erectum Broth. = Plagiothecium latebricola

Plagiothecium euryphyllum var. brevirameum (Cardot.) Z. Iwats. = Plagiothecium euryphyllum

Plagiothecium fujiyamae Sakurai = Plagiothecium cavifolium

Plagiothecium gravetii Piré = Plagiothecium laetum

Plagiothecium hakusanense Sakurai = Plagiothecium euryphyllum

Plagiothecium hattorii Sakurai = Plagiothecium euryphyllum

Plagiothecium ikedamii Sakurai = Plagiothecium cavifolium

Plagiothecium insigne Cardot = Plagiothecium fallax

Plagiothecium kanedae Sakurai = Plagiothecium euryphyllum

Plagiothecium laetum fo. julaceum Jedl. = Plagiothecium curvifolium

Plagiothecium laetum fo. tenellum (Schimp.) Mönk. = Plagiothecium laetum var. tenellum

Plagiothecium laetum subsp. curvifolium (Schlieph. ex Limpr.) Szafran = Plagiothecium curvifolium

Plagiothecium laetum subsp. succulentum fo. longifolium (Mönk.) Jedl. = Plagiothecium succulentum

Plagiothecium laetum var. curvifolium (Limpr.) Mastracci \& M. Sauer = Plagiothecium curvifolium

Plagiothecium laetum var. densum (Schimp.) Warnst. = Plagiothecium laetum

Plagiothecium laetum var. secundum (Lindb.) Frisvoll et al. = Plagiothecium curvifolium

Plagiothecium laetum var. sublaetum (Breidl.) Warnst. = Plagiothecium laetum

Plagiothecium laetum var. tenellum (Schimp.) Warnst. = Plagiothecium laetum

Plagiothecium latifolium Cardot = Plagiothecium neckeroideum var. myurum

Plagiothecium laxum Sakurai = Plagiothecium cavifolium

Plagiothecium longicaule Sakurai = Plagiothecium neckeroideum

Plagiothecium longisetum var. brevinerve Iisiba = Plagiothecium longisetum

Plagiothecium lucens Sauter ex Rabenhorst = Plagiothecium cavifolium

Plagiothecium luridum (Molendo) Molendo \& Lorentz = Plagiothecium laetum

Plagiothecium maedae Sakurai = Plagiothecium neckeroideum

Plagiothecium magufuki Sakurai = Plagiothecium japonicum

Plagiothecium matsumarae S. Okamura = Plagiothecium euryphyllum

Plagiothecium mauiense Broth. = Plagiothecium longisetum

Plagiothecium neckeroideum var. angustatum Cardot = Plagiothecium neckeroideum

Plagiothecium neckeroideum var. argenteus Dixon = Plagiothecium euryphyllum

Plagiothecium neckeroideum var. sikkimense Renauld \& Cardot = Plagiothecium neckeroideum var. myurum

Plagiothecium neglectum Mönkm. = Plagiothecium nemorale

Plagiothecium neglectum subsp. platyphyllum (Mönk.) Szafran = Plagiothecium platyphyllum

Plagiothecium neglectum subsp. platyphyllum fo. fontana (Mönk.) Jedl. = Plagiothecium platyphyllum

Plagiothecium niitakayamae Toyama = Plagiothecium neckeroideum var. niitakayamae

Plagiothecium nipponense Sakurai = Plagiothecium neckeroideum

Plagiothecium nitellum Wilson ex Braithw. = Plagiothecium curvifolium

Plagiothecium obtusifolium (Turner) J. J. Amann = Plagiothecium denticulatum var. obtusifolium

Plagiothecium orthocladium Schimp. = Plagiothecium cavifolium var. orthocladium

Plagiothecium orthothecioides (Meyl.) Jedl. = Plagiothecium ruthei

Plagiothecium otii Sakurai = Plagiothecium cavifolium

Plagiothecium pallidum S. Okamura = Plagiothecium euryphyllum

Plagiothecium podperae Jedl. (Jedl.) = Plagiothecium cavifolium

Plagiothecium pseudolaetum var. japonicum Cardot = Plagiothecium curvifolium

Plagiothecium pseudosylvaticum Warnst. = Plagiothecium ruthei

Plagiothecium ptychocarpum Thér. \& Dixon = Plagiothecium cavifolium

Plagiothecium rigens Broth. = Plagiothecium cavifolium

Plagiothecium roeseanum $($ Hampe $)=$ Plagiothecium cavifolium

Plagiothecium roeseanum fo. angustirete (Warnst.) Jedl. = Plagiothecium cavifolium

Plagiothecium roeseanum fo. flagellaceum (Warnst.) Mönk. = Plagiothecium cavifolium

Plagiothecium roeseanum fo. gracile (Breidl.) Jedl. = Plagiothecium cavifolium

Plagiothecium roeseanum fo. heterophyllum (Warnst.) Jedl. = Plagiothecium cavifolium

Plagiothecium roeseanum fo. propaguliferum R. Rute = Plagiothecium cavifolium

Plagiothecium roeseanum var. gracile Breidl. = Plagiothecium cavifolium

Plagiothecium roeseanum var. gracilescens E. Bauer = Plagiothecium cavifolium

Plagiothecium roeseanum var. julaceum Cardot = Plagiothecium cavifolium

Plagiothecium roeseanum var. flagellaceum Warnst. = Plagiothecium cavifolium

Plagiothecium roeseanum var. orthocladium (Schimp.) Limpr. =Plagiothecium cavifolium var. orthocladium

Plagiothecium roeseanum var. propaguliferum $\mathrm{R}$. Ruthe $=$ Plagiothecium cavifolium

Plagiothecium roesei Milde $=$ Plagiothecium cavifolium

Plagiothecium rosei Schimp. = Plagiothecium cavifolium

Plagiothecium rufovirescens Stirt. = Plagiothecium denticulatum

Plagiothecium ruthei var. gracile Meyl. = Plagiothecium ruthei

Plagiothecium ruthei var. pseudosylvaticum (Warnst.) Warnst. = Plagiothecium ruthei 
Plagiothecium ruthei var. rupestris R. Ruthe = Plagiothecium ruthei

Plagiothecium ruthei var. subundulatum R. Ruthe ex Warnst. = Plagiothecium ruthei

Plagiothecium sakuraii Reimers = Plagiothecium cavifolium

Plagiothecium sandbergii Renauld \& Cardot = Plagiothecium denticulatum var. obtusifolium

Plagiothecium saxicola Sakurai = Plagiothecium nemorale

Plagiothecium silvaticum Bruch \& Schimp. in Lindb. = Plagiothecium sylvaticum

Plagiothecium silvaticum var. latifolium Cardot = Plagiothecium nemorale

Plagiothecium silvaticum var. nemorale (Mitt.) Par. = Plagiothecium nemorale

Plagiothecium silvaticum var. rhynchostegioides Cardot $=$ Plagiothecium nemorale

Plagiothecium solutans Mol. ex Warnst. = Plagiothecium curvifolium

Plagiothecium splendens Schimp. ex Cardot = Plagiothecium euryphyllum

Plagiothecium splendens var. brevirameum Cardot = Plagiothecium euryphyllum

Plagiothecium splendens var. minus Cardot = Plagiothecium euryphyllum

Plagiothecium splendens var. paraphylliferum Sakurai = Plagiothecium euryphyllum

Plagiothecium splendens var. punctatum Sakurai = Plagiothecium euryphyllum

Plagiothecium stoloniferum Velen. = Plagiothecium ruthei

Plagiothecium subdenticulatum Correns = Plagiothecium ruthei

Plagiothecium sublaetum (Lindb.) Lindb. = Plagiothecium laetum

Plagiothecium succulentum fo. lignicolum Jedl. = Plagiothecium succulentum fo. propaguliferum

Plagiothecium succulentum var. fontanum (Schiffn.) Riehm. = Plagiothecium platyphyllum

Plagiothecium succulentum var. longifolium Mönk = Plagiothecium succulentum fo. propaguliferum

Plagiothecium sullivantiae (Schimp. ex Sull.) A.Jaeger = Plagiothecium cavifolium

Plagiothecium sylvaticum (Brid.) Schimp. = Plagiothecium denticulatum

Plagiothecium sylvaticum auct. non. (Brid.) Bruch \& Schimp. = Plagiothecium nemorale

Plagiothecium sylvaticum auct. non. Hypnum sylvaticum Brid. = Plagiothecium nemorale

Plagiothecium sylvaticum subsp. roesei Lindb. (Kindb.) = Plagiothecium cavifolium

Plagiothecium sylvaticum subsp. succulentum (Wils.) J.J. Amann \& Meyl. = Plagiothecium succulentum

Plagiothecium sylvaticum var. auritum Kern = Plagiothecium ruthei

Plagiothecium sylvaticum var. cavifolium Jur. = Plagiothecium cavifolium

Plagiothecium sylvaticum var. cryptarum (Renauld \& Hérib.) P.Syd. = Plagiothecium cavifolium

Plagiothecium sylvaticum var. flavescens Warnst. = Plagiothecium platyphyllum

Plagiothecium sylvaticum var. fluitans Podp. = Plagiothecium platyphyllum

Plagiothecium sylvaticum var. fontanum Schiffn. = Plagiothecium platyphyllum

Plagiothecium sylvaticum var. latifolium Cardot = Plagiothecium nemorale

Plagiothecium sylvaticum var. laxum Molendo = Plagiothecium cavifolium

Plagiothecium sylvaticum var. monoricum Breidl. in Limpr. = Plagiothecium ruthei var. rupincola

Plagiothecium sylvaticum var. myurum Molendo = Plagiothecium cavifolium

Plagiothecium sylvaticum var. neglectum (Mönk.) F. Koppe = Plagiothecium nemorale

Plagiothecium sylvaticum var. nemorale (Mitt.) Paris $\equiv$ Plagiothecium nemorale

Plagiothecium sylvaticum var. nervosum Renauld = Plagiothecium platyphyllum

Plagiothecium sylvaticum var. orthocladium (Schimp.) Schimp. = Plagiothecium cavifolium var. orthocladium

Plagiothecium sylvaticum var. phyllorhizans Spruce = Plagiothecium platyphyllum

Plagiothecium sylvaticum var. platyphyllum (Mönk) F. Koppe = Plagiothecium platyphyllum

Plagiothecium sylvaticum var. pseudoneckeroideum Schiffn. = Plagiothecium ruthei

Plagiothecium sylvaticum var. pseudo-roeseanum $\mathrm{Cardot}=$ Plagiothecium cavifolium

Plagiothecium sylvaticum var. rhynchostegioides Cardot = Plagiothecium nemorale

Plagiothecium sylvaticum var. rivulare Debat = Plagiothecium nemorale

Plagiothecium sylvaticum var. robustum Roell. = Plagiothecium ruthei

Plagiothecium sylvaticum var. roeseanum (Schimp.) A. W. H. Walther \& Molendo = Plagiothecium cavifolium

Plagiothecium sylvaticum var. squarrosum Kind. = Plagiothecium platyphyllum

Plagiothecium sylvaticum var. succulentum (Wilson) Spruce = Plagiothecium succulentum

Plagiothecium sylvaticum var. sullivantiae (Sull.) Ren. \& Card. = Plagiothecium cavifolium

Plagiothecium takahashii Sakurai = Plagiothecium cavifolium

Plagiothecium trichodeum Stirt. = Plagiothecium denticulatum

Plagiothecum ruthei var. subjulaceum Warnst. = Plagiothecium cavifolium

Plagiothecium ruthei var. orthothecioides Meyl. = Plagiothecium platyphyllum

Rectithecium piliferum (Sw.) Hadenäs \& Huttunen = Plagiothecium piliferum

Saviczia obtusissima (Broth.) Abramova \& I. I. Abramov = Plagiothecium obtusissimum

Plagiothecium watanabei Dixon = Plagiothecium euryphyllum

Stereodon denticulatus (Hedw.) Mitt. = Plagiothecium denticulatum

Stereodon nemoralis Mitt. $\equiv$ Plagiothecium nemorale

Stereodon sylvaticus (Brid.) Brid. = Plagiothecium denticulatum

Struckia argentata (Mitt.) Müll. Hal. = Plagiothecium argentatum

Struckia argentata var. enervis (Broth.) B. C. Tan, W. R. Buck \& Ignatov = Plagiothecium enerve

Struckia enervis (Broth.) Ignatov, T. J. Kop. \& D. G. Long = Plagiothecium enerve

\section{Appendix B}

Checklist of the Plagiothecium taxa in Eurasia. Under each taxon, a list of countries and islands on which it was recorded is given along with relevant literature. The taxa are arranged alphabetically under phylogenetically based sectional classification of Plagiothecium established by Wynns [7] and Wynns et al. [23], with appropriate changes used in this manuscript.

Plagiothecium Schimp. sect. Plagiothecium Type: Hypnum denticulatum Hedw. Species Muscorum Frondosorum 237. 1801.

1. Plagiothecium conostegium Herzog 1916. Bibiotheca Botanica 87: 154. f. 73: a-d.

JAP [119]. 
2. Plagiothecium denticulatum (Hedw.) Schimp. in BSG 1851. Bryologia Europea 5: 190, 501 (Table VIII).

ALB [9,48]; AND [9,47,48,51,52]; ARM [32,53]; AUT [7,9,48,54]; AZE [32]; AZO [47]; BGM [7,9,48,62]; BAN [59,60]; BUL [9,48,49,68]; BIH [9,47-49]; BLR [9,32,48,61,228]; CHI [9,48]; SWI $[9,48,176,177]$; CHN [77-80]; COR [9,47,48,62]; CZE [7,9,48,84]; GER [7,9,48,95,96,98]; DEN [7,9,30,48,87]; SPA [9,47,48,51,167]; EST [9,32,48,88]; FIN [7,9,28,48,91,92]; FRA [9,47,48,94]; FRO [7,9,48,89,90]; GRB [7,9,25,48,109]; GEO [32]; GRC [9,47-49]; CRO [9,47-49]; HUN [9,48,99]; IND [103]; IRE [9,25,48,109]; IRN [45,110]; IRQ [106,107]; ICE [9,48,102]; ITA [9,48,114,115]; JAP [33,34,78,118]; KAZ; KGZ [32]; KOS [9]; SKO [78,86]; LAV [9,32,48,124]; LIE [9,48,126]; LTU [9,32,48,127]; LUX [9,48,129,130]; MDR [9,47,131]; MKD [9,47-49,145]; MNE [9,47-49]; MON [139]; NET [9,48,143,144]; NOR [7,9,48]; NEP [142]; PAK [149-151]; POL [7,9,48,154]; NKO [78,86]; POR [9,47,48,51,155]; ROM [9,48,49,158]; RUS [32,48,159]; SAR [9,48]; SIC [9,47,48]; SVA [9,48,173]; SRB [9,47-49]; SVK [9,48,164]; SVN [9,47-49]; SWE [7,9,48,174,175]; TZK [32]; TUR [9,45,47-49,180,181]; UKR [9,32,48,183,185].

3. Plagiothecium denticulatum var. affine Warnst. 1906. Kryptogamenflora der Mark Brandenburg, Laubmoose 822, 838: f. 1.

GER [7].

4. Plagiothecium denticulatum var. obtusifolium (Turner) Moore 1873. Proceedings of the Royal Irish Academy 1: 424.

BUL [9,47,48]; SWI [7]; CHN [7,79,80]; CZE [7,9,48,84]; GER [7]; SPA [47,48,167]; FIN [7,9,48]; FRA [7,9,47,48,94]; GRB [9,25,48,109]; HUN [7]; IRE [9,25,48,109]; IRN [43,45,110]; ICE [7]; ITA [9,47,48,115-117]; JAP [33,118]; KOS [9,120]; LUX [9,48,129,130]; NEP [7]; POL [9,48,154]; RUS [7,32,48,162]; SVN [9,48]; SWE [7,9,48,174,175]; TUR [9,45,47,48,181]; UKR [9,32,48].

5. Plagiothecium platyphyllum Mönk. 1927. Die Laubmoose Europas 866. f. 207b.

AND [9,52]; AUT [7,9,48,54]; BUL [9,47-49,68]; SWI [9,48,176,177]; CHN [77,79,80]; COR [9,47,48,62]; CZE [7,9,48,84]; GER [7,9,48,95,97,98]; DEN [30]; SPA [9,47,48,51,167]; FIN [7,9,28,48,91-93]; FRA [9,47,48,78,94]; GRB [7,9,25,48]; GEO [32]; GRC [9,48]; CRO [9,83]; HUN [7,9,48,99]; IRE [9,25,48,109]; IRN [43,45,110]; ITA [9,47,48,114,117]; JAP [78]; KOS [9,120]; SKO [78]; LTU [9,128]; LUX [9,48,129,130]; MKD [9,47-49]; MNE [9,47-49]; NOR [7,9,48]; POL [9,48,154]; NKO [78]; POR [9,156]; ROM [9,48,49,158]; RUS [32,48,159]; SRB [9,47-49]; SVK $[9,48,164]$; SVN [9,47-49]; SWE [7,9,48,174,175]; TUR [9,43,45,47-49,180,181]; UKR $[9,32,48,184]$.

6. Plagiothecium ruthei Limpr. 1877. Die Laubmoose Deutschlands, Oesterreichs und der Schweiz 3: 271.

AUT [9,48,54]; BUL [47,68]; BLR [9,48]; SWI [7,9,48,176,177]; CHN [77]; CZE [9,48,84]; GER $[7,9,48,95,96,98]$; DEN $[7,9,30,48,87]$; SPA $[9,47,48,167]$; EST [9,32,48,88]; FIN $[7,9,48,91,92]$; FRA [9,47,48,94]; GRB [9,25,48,109]; HUN [9,48,99]; IRE [25,109]; ITA [47,48,114];JAP [33,118]; LAV [9,32,48,124]; LIE [9,48,126]; LTU [9,32,48,127]; LUX [9,48,117,129,130]; NET [7,9,48,143,144]; POL [7,9,48,154]; ROM [9,48]; RUS [32,48,159]; SVK [9,48,164]; SWE [9,48,174,175]; UKR $[9,32,48,185]$.

7. Plagiothecium ruthei var. rupincola Limpr. 1897 Die Laubmoose Deutschland Oesterreich und der Schweiz 3: 273.

\section{AUT; CZE; GER; FRA; NOR; SWE [7].}

Plagiothecium sect. Orthophyllum Jedl. Spisy Prír. Fak. Masarykovy Univ. 308: 35.1948.

8. Plagiothecium angusticellum G. J. Wolski \& P. Nowicka-Krawczyk 2020. PLOS ONE 15(3): e0230237.

CZE; EST; HUN; LAV; LTU; POL [27].

9. Plagiothecium cavifolium (Brid.) Z. Iwats. 1970. Jounral of the Hattori Botanical Labolatory 33: 360. 
ALB [9,48]; AND [9,52]; AUT [9,48,54]; AZE [32]; BGM [9,48,62]; BUL [9,47-49,68]; BIH [9,47-49]; BHU [63,64]; BLR [9,32,48,61,228]; SWI [7,9,48,176,177]; CHN [7,64,77-80]; COR [9,47,48,62]; CZE [7,9,48,84]; GER [7,9,48,95,96,98]; DEN [7,9,30,48,87]; SPA [9,47,48,51,167]; EST [9,32,48,88]; FIN [9,28,48,91,92]; FRA [7,9,47,48,94]; FRO [9,48,89,90]; GRB [9,25,48,109]; GEO [32]; GRC [9,47-49]; CRO [9,47-49]; HUN [7,9,48,99]; IND [64,103]; IRE [9,25,48,109]; IRN [111]; ICE [7,9,48,102]; ITA [9,47,48,114-117]; JAP [7,33,34,64,78,118]; KAZ [32]; SKO [64,78]; LAO [78]; LAV [7,9,32,48,124]; LIE [9,48]; LTU [9,32,48,127]; LUX [9,48,129,130]; MOL [9,32,48]; MKD [9,47-49,145]; MNE [9,47-49]; MON [139]; NET [9,48,143,144]; NOR [9,48]; NEP [64,142]; PAK [148,149,151]; POL [7,9,48,154]; NKO [64,78]; POR [9,47,48,51,155]; ROM [9,48,49,158]; RUS [7,48,64,159]; SIC [9,47,48]; SRB [9,47-49]; SVK [9,48,164]; SVN [9,47-49]; SWE [9,48,174,175]; TUR [9,45,47-49,181]; TAI [178]; UKR [9,32,48,183,185].

10. Plagiothecium cavifolium var. orthocladium (Schimp.) Z. Iwats. 1970 Jounral of the Hattori Botanical Labolatory 33: 371.

FIN; FRO; SWE [7].

11. Plagiothecium cochleatum Dixon 1938. Notes on the moss collections of the Royal Botanic Garden, Edinburgh. Notes from the Royal Botanic Garden, Edinburgh 19: 299. f. 12 .

IND $[7,104]$.

12. Plagiothecium japonicum Salurai 1949. Botanical Magazine (Tokyo) 62: 112. f. 1 .

JAP [7].

13. Plagiothecium longisetum Lindb. 1872. Contributio ad Floram Cryptogamam Asiae Boreali-Orientalis 232.

AUT; AZO; BGM; SWI; CHN; GER; DEN; SPA; EST; FIN; FRA; GRB; GEO; IND; IRN; JAP; MDR; NEP; NOR; POL; RUS; SWE; TUR [27].

14. Plagiothecium nemorale (Mitt.) A. Jaeger 1878. Bericht über die Thätigkeit der St. Gallischen Naturwissenschaftlichen Gesellschaft 1876-77: 451 (Gen. Sp, Musc. 2: 1269).

ALB [9,47-49]; AND [9,47,48,51,52]; ARM [32,53]; AUT [9,27,48,54]; AZE (Ignatov et al. 2006) [32]; AZO [9,47,48,55-57]; BGM [9,27,48,62]; BUL [9,47-49,68]; BIH [9,47-49]; BHU [7,63]; BLR [9,32,48,61,228]; CNY [9,47,48]; CHI [9,48]; SWI [9,48,176,177]; CHN $[7,27,66,77-80]$; COR [9,47,48,62]; CZE [7,9,27,48,84]; GER [7,9,27,48,95,96,98]; DEN $[7,9,27,30,48,87]$; SPA [9,47,48,51,167]; EST [9,27,32,48,88]; FIN [9,28,48,91-93]; FRA [7,9,27,47,48,94]; FRO [90]; GRB [7,9,25,27,48,109]; GEO [27,32]; GRC [9,47-49]; CRO [47,48,82]; HUN [7,9,27,48,99]; IND [7,27,103]; IRE [9,25,48,109]; IRN [7,27,43,45,111]; ITA $[7,9,27,47,48,114-117] ;$ JAP $[7,27,33,34,66,78,118]$; KOS [9,120]; SKO $[7,66,78,86]$; LAV [9,27,32,48,124]; LIE [9,48,126]; LTU [9,27,32,48,127]; LUX [9,48,129,130]; MDR [9,47,48,51,131]; MKD [9,47-49,145]; MYA [72]; MNE [9,47-49]; NET [9,48,143,144]; NOR [9,27,48]; NEP [7,141,142]; PAK [150,151]; PHI [152,153]; POL [9,27,48,154]; NKO [7,66,78,85,86]; POR [9,27,47,48,51,155]; ROM [9,48,49,158]; RUS [7,32,48,66,78,159]; SAR [9,47,48]; SIC [9,47,48]; SRB [9,47-49]; SVK [9,27,48,164]; SVN [9,47-49,165]; SWE [7,9,27,48,174,175]; TUR [7,9,27,43,45,47-49,180,181]; TAI [66,78,178]; UKR [9,32,48,183,185]; VIE [189].

15. Plagiothecium rhizophyllum Sakurai 1932. Botanical Magazine (Tokyo) 46: 501. CHN [7].

16. Plagiothecium succulentum (Wilson) Lindb. 1865. Botaniska Notiser 1865: 143.

ALB [9,48]; AND [52]; AUT [9,48,54]; AZO [9,47,48,55-57]; BGM [9,48,62]; BUL; BIH [9,47-49]; BLR [9,48]; CNY [9,47,48,74]; CHI [9,48]; SWI [9,48,176,177]; CHN [77,79,80]; COR [9,47,48,62]; CZE [7,9,48,84]; GER [7,9,48,95,96,98]; DEN [7,9,30,48,87]; SPA [9,47,48,51,167]; EST $[9,32,48,88]$; FIN $[9,28,48,91]$; FRA [9,47,48,78,94]; FRO [7,9,48,89,90]; GRB [9,25,48,109]; GEO (Ignatov et al. 2006) [32]; GRC [9,47-49]; HUN [9,48,99]; IRE [9,25,48,109]; IRN [45,110]; ICE [9,48,102]; ITA [9,47,48,114,116,117]; SKO [78]; KOS [9,120]; LAV [9,32,48,124]; 
LTU [9,32,48,127]; LUX [9,48,129,130]; MDR [9,47,48,51,131,132]; MKD [9,146]; MNE; NOR [9,48]; NET [9]; POL [9,48,154]; NKO [78]; POR [9,47,48,51,155]; ROM [9,48,49,158]; RUS [32,48,162]; SRB [9,47-49]; SVK [9,48,164]; SVN [9,47-49]; SWE [7,9,48,174,175]; TUR [9,45,47-49,181]; UKR [9,32,48,184,185].

17. Plagiothecium succulentum fo. propaguliferum E. Bauer 1902. Deutsche Botanische Monatsschrift 20: 2.

AUT; CZE; GER; DEN; LAV [7].

Plagiothecium sect. Leptophyllum Jedl. Spisy Prír. Fak. Masarykovy Univ. 308: 23. 1948.

18. Plagiothecium berggrenianum Frisvoll 1981. Lindbergia 7: 96. f. 2: a-i.

RUS [7,26,32,48,159]; SVA [7,9,48,171-173].

19. Plagiothecium curvifolium Schlieph. ex Limpr. 1897. Die Laubmoose Deutschlands, Oesterreichs und der Schweiz 3: 269.

ALB; AUT [9,48]; BGM [9,48,62]; BUL [9,47,48]; BIH [9,47-49]; CHI [9,48]; SWI [9,48,177]; CHN [77,79,80]; COR [9,47,48,62]; CZE [7,9,48,84]; GER [7,9,26,48,95,98]; DEN [7,9,30,48,87]; SPA [9,47,48,51,167]; EST [9,32,48,88]; FIN [9,28,48,91,92]; FRA [9,47,48,94]; GRB [9,25,48,109]; GRC [9,47-49]; CRO [9,83]; HUN [9,48,100]; IRE [9,25,48,109]; ITA [9,47,48,116,117]; JAP [34]; KOS [9,120]; LAV [7,9,32,48,124]; LIE [9,48,126]; LTU [9,32,48,127]; LUX [9,48,129,130]; MKD [9,47,48]; MNE [9,47-49]; NET [9,143]; NOR [9,48]; POL [7,9,26,48,154]; ROM [9,48,49,158]; RUS [26,32,48,161,162]; SRB [9,47-49]; SVK [7,9,48,164]; SVN [9,47-49]; SWE [9,48,174,175]; TUR [9,45,47-49,181]; UKR [9,26,32,48,185].

20. Plagiothecium curvifolium fo. julaceum Clum. \& E. Bauer 1915. Musci Europaei Exsiccati 27: 1307.

SWI [7].

21. Plagiothecium laetum Schimp. in BSG 1851. Bryologia Europaea 5: 185, 495 (Table II).

ALB [9,50]; AND [9,47,48,51,52]; AUT [9,26,48]; AZE [32]; BGM [7,9,48,62]; BUL [9,47-49,68]; BIH [9,26,47-49]; BLR [9,32,48,61,228]; SWI [9,48,176,177]; CHN [77,79,80]; CZE [7,9,26,48,84]; GER [7,9,26,48,95,96,98]; DEN [7,9,30,48,87]; SPA [9,47,48,51,167]; EST [9,32,48,88]; FIN [7,9,26,28,48,91,92]; FRA [9,47,48,94]; GRB [9,25,48,109]; GEO [32]; GRC [9,47-49]; HUN [9,26,48,99]; IRE [9,25,48,109]; IRN [43,45,110]; ITA [9,47,48,114-117]; JAP [33,78,118]; KAZ; KGZ [32]; KOS [9,120]; SKO [78]; LAV [9,32,48,124]; LIE [9,48,126]; LTU [9,32,48,127]; LUX [9,48,129,130]; MDR [47,51,132]; MNE [9,47-49]; MON [139]; NET [9,48,143,144]; NOR [9,26,48]; POL [7,9,26,48,154]; NKO [78]; [47,48,51]; ROM [9,48,49,158]; RUS [7,26,32,48,159]; SRB [9,47-49]; SVK [9,48,164]; SVN [9,47-49,165]; SWE [7,9,26,48,174,175]; TUR [7,45,47,181]; TAI [66]; UKR [9,32,48,183,185].

22. Plagiothecium laetum var. tenellum (Schimp.) Warnst. 1906. Kryptogamenflora der Mark Brandenburg, Laubmoose 835.

BGM [7].

23. Plagiothecium latebricola Wilson ex Schimp. in BSG 1851. Bryologia Europaea 5: 184, 494 (Table I).

AUT [9,48,54]; BGM [7,9,48,62]; BLR [9,32,48,61,228]; SWI [48]; CHN [76,77,79,80]; CZE [9,48,84]; GER [9,48,95,96,98,222]; DEN [7,9,30,48,87]; EST [9,32,48,88]; FIN [7,9,28,48,91-93]; FRA [9,47,48]; GRB [7,9,25,48,109]; GEO [32]; HUN [9,101]; IRE [9,25,48,109]; ITA [9,47,48,114,117]; JAP [33,34,118]; KGZ [32]; LAV [9,32,48,124]; LTU [9,32,48,127]; SRL [170]; LUX [9,48,129,130]; NET [7,9,143,144]; NOR [9,48]; PAK [150,151]; POL [9,48,154]; POR [9,47,48,155]; ROM [9,48,49,158]; RUS [32,48,159]; SRB [9,47-49]; SVK [9,48,164]; SWE [9,48,174,175]; TUR [43,45,47,180,181]; UKR $[9,32,48,185]$.

24. Plagiothecium rossicum Ignatov \& Ignatova 2019. Arctoa 28: 28-45.

POL; RUS $[9,26]$. 
25. Plagiothecium svalbardense Frisvoll 1996. Norsk Polarinstitutt Skrifter 198: 103. RUS [26,32,160,162]; SVA [7,9,26,48,173]; SWE [7,26].

Plagiothecium sect. Pseudo-Neckera (Kindb.) J.T. Wynns 2015

26. Plagiothecium decoratum J. T. Wynns 2015. Molecular phylogeny and systematic revision of the pleurocarpous moss genus Plagiothecium. PhD Thesis, University of Copenhagen: 126 .

BHU; NEP [7].

27. Plagiothecium neckeroideum Schimp. in BSG 1851. Bryologia Europea 5: 194, 505 (Table XII).

AUT [7,9,48,54]; BOR [65,66]; BHU [63]; SWI [7,9,48,176,177]; CHN [7,66,77-80]; CZE [9,48,84]; GER [7,9,48,95,97,98]; IDN [105]; IND [78,103]; JAP [7,33,34,66,78,118]; SKO [78]; MLY [133]; NEP [7,142]; PHI [7,66,152,153]; NKO [78]; ROM [9,48,49,158]; RUS [32,66,78,159]; SIN [133]; SUM [66,105]; SVN [9,47-49,166]; THA [66,72,179]; TAI [66,178]; UKR [9,32,48,184].

28. Plagiothecium neckeroideum fo. exile J. T. Wynns 2015. Molecular phylogeny and systematic revision of the pleurocarpous moss genus Plagiothecium. PhD Thesis, University of Copenhagen: 210.

NEP [7].

29. Plagiothecium neckeroideum var. javense M. Fleisch. 1920. Die Musci der Flora von Buitenzorg 4: 1168. f. 194.

IDN [7]; PHI [152,153]; SUM [105].

30. Plagiothecium neckeroideum var. myurum Molendo 1875. Jahres-Bericht de Naturhistirischen Vereins in Passau 10: 234.

BHU; CHN, IND; NEP [7].

31. Plagiothecium neckeroideum var. niitakayamae (Toyama) Z. Iwats. 1970. Journal of the Hattori Botanical Laboratory 33: 354.

CHN [7,79,80]; JAP [29,118]; PHI [153]; TAI [66,77,178].

32. Plagiothecium neckeroideum fo. paroum J. T. Wynns 2015. Molecular phylogeny and systematic revision of the pleurocarpous moss genus Plagiothecium. PhD Thesis, University of Copenhagen: 213.

TAI [7].

33. Plagiothecium noricum Molendo ex Limpr. 1897. Die Laubmoose Deutschlands, Oesterreichs und der Schweiz 3: 257.

AUT [7]; MYA [140].

34. Plagiothecium subglaucum Thwaites and Mitt. 1873. Journal of the Linnean Society, Botany 13: 321.

SRL [7,168,169]; MYA [140].

Plagiothecium sect. Lycambium Jedl. 1948. Spisy Prír. Fak. Masarykovy Univ. 308: 10. 1948.

35. Plagiothecium fallax Cardot \& Thér. 1902. Proceedings of the Washington Academy of Sciences 4: 336. pl. 22: f. 4.

JAP; RUS [7].

36. Plagiothecium undulatum (Hedw.) Schimp. in BSG 1851. Bryologia Europea 5: 195, 506 (Table XIII). 
AUT [9,48,54]; AZE [32]; BGM [9,48,62]; BUL [9,47-49,68]; BIH [47-49]; BLR [9,32,48,228]; CHI [9,48]; SWI [9,48,176,177]; CHN [77,79]; CZE[9,48,84]; GER [7,9,48,95,96,98]; DEN [7,9,30,48,87]; SPA [9,47,48,51,167]; EST [9,32,48,88]; FIN [9,28,48,91,92]; FRA [7,9,47,48,94]; FRO [7,9,48,89,90]; GRB [7,9,25,48,109]; CRO [9,47-49]; HUN [9,48,99,100]; IRE [9,25,48,109];IRN [43,45,110]; ITA [9,47,48,114-117]; LAV [9,32,48,124]; LIE [9,48,126]; LTU [9,32,48,127]; LUX [9,48,129,130]; NET [9,48,143,144]; NOR [9,48]; POL [7,9,48,154]; POR [9,47,48,51]; ROM [9,48,49,158]; RUS [32,48,159]; SIC [9,47,48]; SRB [9,47-49]; SVK [9,48,164]; SVN [9,47-49]; SWE [7,9,48,174,175]; TUR [43,45,47,180,181]; UKR [9,32,48,184].

Plagiothecium sect. Saviczia (Abramova \& I. I. Abramov) Z. Iwats. J. Hattori Bot. Lab. 33: 341. 1970.

37. Plagiothecium euryphyllum (Cardot \& Thér.) Z. Iwats. 1970. Jounral of the Hattori Botanical Labolatory 33: 348.

BHU [64]; CHN [7,64,77,79,80]; IND [64]; JAP [7,33,34,64,78,118]; MYA [140]; SKO; NKO [64,78]; RUS [32,161,162]; TAI [78,178]; VIE [72,188,189].

38. Plagiothecium obtusissimum Broth. 1921. Oefversigt at Förhandlingar, Finska VetenskapsSocieteten $62 \mathrm{~A}(9): 45$.

JAP [7,33,34]; RUS [32,159].

Plagiothecium sect. Struckia (Müll. Hal.) J.T. Wynns 2015

39. Plagiothecium argentatum (Mitt.) Q. Zuo 2011. Journal of Bryology 33(3): 227. CHN [7,36]; IND; NEP [7].

40. Plagiothecium enerve (Broth.) Q. Zuo 2011. Journal of Bryology 33(3): 227. CHN [7,36]; RUS [7].

Plagiothecium sect. Rectithecium (Hedenäs \& Huttunen) J. T. Wynns 2015

41. Plagiothecium piliferum (Sw.) Schimp. in BSG 1851. Bryologia Europea 5: 186, 496 (Table III).

AND [9,52]; SWI [9,48,176,177]; CHN [77-80]; COR [9,47,48,62]; DEN [30]; SPA [9,47,48,51,167]; FIN [7,9,28,48,91,92]; FRA [9,47,48,78,94]; GRB [7,9,25,48,109]; IRE [25,109]; ITA [9,47,48,114,115,117]; JAP [33,78]; SKO [78]; LAV [9,125]; NOR [7,9,48]; NKO [78]; POR [9,47,48,51,155]; ROM [9,48,49,158]; RUS [7,32,48,78,159]; SAR [9,47,48]; SVN [9,47-49,165]; SWE [7,9,48,174,175]; TUR [47,182]; UKR [9,32,48,184,185].

\section{References}

1. Bruch, P.; Schimper, W.P.; Gümbel, W.T. Bryologia Europaea Seu Genera Muscorum Europaeorum Monographice Illustrata; Schimper, W.P., Ed.; Sumptibus Librariae E. Schweizerbart: Stuttgart, Germany, 1851; Volume 5.

2. Buck, W.R.; Ireland, R.R. A Reclassification of the Plagiotheciaceae. Nova Hedwig. 1985, 41, 89-125.

3. Buck, W.R.; Ireland, R.R. Plagiotheciaceae. Flora Neotropica, Monograph 50; The New York Botanical Garden: New York, NY, USA, 1989.

4. Buck, W.R. Plagiotheciaceae. In Pleurocarpous Mosses of the West Indies; The New York Botanical Garden: New York, NY, USA, 1998; pp. 295-299.

5. Pedersen, N.; Hedenäs, L. Phylogenetic Relationships within the Plagiotheciaceae. Lindbergia 2001, 26, 62-76.

6. Pedersen, N.; Hedenäs, L. Phylogeny of the Plagiotheciaceae Based on Molecular and Morphological Evidence. Bryologist 2002, 105, 310-324. [CrossRef]

7. Wynns, J.T. Molecular Phylogeny and Systematic Revision of the Pleurocarpous Moss Genus Plagiothecium. Ph.D. Thesis, University of Copenhagen, Copenhagen, Denmark, 2015.

8. Hodgetts, N.G.; Söderström, L.; Blockeel, T.L.; Caspari, S.; Ignatov, M.S.; Konstantinova, N.A.; Lockhart, N.; Papp, B.; Schröck, C.; Sim-Sim, M.; et al. An Annotated Checklist of Bryophytes of Europe, Macaronesia and Cyprus. J. Bryol. 2020, 42, 1-116. [CrossRef]

9. Hodgetts, N.; Lockhart, N. Checklist and Country Status of European Bryophytes-Update 2020; Irish Wildlife Manuals, No. 123.; National Parks and Wildlife Service. Department of Culture, Heritage and the Gaeltacht: Dublin, Ireland, 2020.

10. O'Shea, B.J. Checklist of the Mosses of Sub-Saharan Africa (Version 5, 12/06). Trop. Bryol. Res. Rep. 2006, 6, 1-255. 
11. Ochyra, R. Plagiothecium lamprostachys (Hampe) A.Jaeger (Plagiotheciaceae), a Forgotten Name for an Australasian Moss. J. Bryol. 2002, 24, 85-86. [CrossRef]

12. Ros, R.M.; Cano, M.J.; Guerra, J. Bryophyte Checklist of Northern Africa. J. Bryol. 1999, 21, 207-244. [CrossRef]

13. Schultze-Motel, W. Katalog Der Laubmoose von West-Afrika. [Catalogue of Mosses of West-Africa]. Willdenowia 1975, 7, 473-535.

14. Ochyra, R.; Lewis-Smith, R.I.; Bednarek-Ochyra, H. The Illustrated Moss Flora of Antarctica; Cambridge University Press: Cambridge, $\mathrm{UK}, 2008$.

15. Ochyra, R.; Bednarek-Ochyra, H.; Lewis Smith, R.I. New and Rare Moss Species from Subantarctic South Georgia. Nova Hedwig. 2002, 74, 121-147. [CrossRef]

16. Ireland, R.R. Studies of the Genus Plagiothecium in Australasia. Bryologist 1992, 95, 221-224. [CrossRef]

17. Klazenga, N. Australian Mosses Online 18. Plagiotheciaceae. Australian Biological Resources Study, Canberra. 2012. Available online: http:/ / www.anbg.gov.au/abrs/Mosses_online/18_Plagiotheciaceae.html (accessed on 29 January 2020).

18. Ireland, R.R. A Taxonomic Revision of the Genus Plagiothecium for North America, North of Mexico; National Museum of Natural Sciences Publications in Botany, The National Museums of Canada: Ottawa, ON, Canada, 1969.

19. Ireland, R.R. Synopsis of the Genus Plagiothecium in North America. Lindbergia 1986, 12, 49-56.

20. Anderson, L.E.; Crum, H.A.; Buck, W.R. List of the Mosses of North America North of Mexico. Bryologist 1990, 93, 448-499. [CrossRef]

21. Ireland, R.R. Family Plagiotheciaceae. In Flora of North America North of Mexico; Flora of North America Editorial Committee, Ed.; Oxford University Press: Oxford, UK; New York, NY, USA, 2014; Volume 28, pp. 483-488, ISBN 978-0-19-020275-0.

22. Churchill, S.P.; Griffin, D.G.; Muñoz, F.J. A Checklist of the Mosses of the Tropical Andean Countries; Monografías del Real Jardín Botánico; Consejo Superior de Investigaciones Científicas: Madrid, Spain, 2000; Volume 17, ISBN 978-84-00-07993-2.

23. Wynns, J.T.; Munk, K.R.; Lange, C.B.A. Molecular Phylogeny of Plagiothecium and Similar Hypnalean Mosses, with a Revised Sectional Classification of Plagiothecium. Cladistics 2018, 34, 469-501. [CrossRef]

24. Wolski, G.J. Are Plagiothecium cavifolium, P. nemorale and P. succulentum Indeed Variable Species? Pak. J. Bot. 2018, 50, 1579-1589.

25. Smith, A.J.E. The Moss Flora of Britain and Ireland, 2nd ed.; Cambridge University Press: Cambridge, UK, 2004; ISBN 978-0-521-54672-0.

26. Ignatova, E.A.; Fedorova, A.V.; Kuznetsova, O.I.; Ignatov, M.S. Taxonomy of the Plagiothecium laetum Complex (Plagiotheciaceae, Bryophyta) in Russia. Arctoa 2019, 28, 28-45. [CrossRef]

27. Wolski, G.J.; Nowicka-Krawczyk, P. Resurrection of the Plagiothecium longisetum Lindb. and Proposal of the New Species-P. angusticellum. PLoS ONE 2020, 15, e0230237. [CrossRef] [PubMed]

28. Nyholm, E. Illustrated Moss Flora of Fennoscandia; CWK Gleerup: Lund, Sweden, 1965; Volume 2.

29. Iwatsuki, Z. A Revision of Plagiothecium and Its Related Genera from Japan and Her Adjacent Areas. J. Hattori Bot. Lab. 1970, 33, 332-385.

30. Lewinsky, J. The Family Plagiotheciaceae in Denmark. Lindbergia 1974, 2, 185-217.

31. Hill, M.O.; Bell, N.; Bruggeman-Nannenga, M.A.; Brugues, M.; Cano, M.J.; Enroth, J.; Flatberg, K.I.; Frahm, J.-P.; Gallego, M.T.; Garilleti, R.; et al. An Annotated Checklist of the Mosses of Europe and Macaronesia. J. Bryol. 2006, 28, 198-267. [CrossRef]

32. Ignatov, M.S.; Afonina, O.M.; Ignatova, E.A.; Ābolina, A.; Akatova, T.V.; Baisheva, E.Z.; Bardunov, L.V.; Baryakina, E.A.; Belkina, O.A.; Bezgodov, A.G.; et al. Check-List of Mosses of East Europe and North Asia. Arctoa 2006, 15, 1-130. [CrossRef]

33. Suzuki, T. A Revised New Catalog of the Mosses of Japan. Hattoria 2016, 7, 9-223. [CrossRef]

34. Noguchi, A. Illustrated Moss Flora of Japan; Hattori Botanical Laboratory: Nichinan, Japan, 1994; Volume 5, ISBN 978-4-938163-09-9.

35. Huttunen, S.; Ignatov, M.S.; Quandt, D.; Hedenäs, L. Phylogenetic Position and Delimitation of the Moss Family Plagiotheciaceae in the Order Hypnales. Bot. J. Linn. Soc. 2013, 171, 330-353. [CrossRef]

36. Zuo, Q.; Higuchi, M.; Wang, Y.F.; Arikawa, T.; Hirayama, Y. The Status of Struckia Müll.Hal. (Plagiotheciaceae, Bryopsida) Inferred from Multiple Nuclear and Chloroplast Loci. J. Bryol. 2011, 33, 221-228. [CrossRef]

37. Wynns, J.T.; Schröck, C. Range Extensions for the Rare Moss Plagiothecium handelii, and Its Transfer to the Resurrected Genus Ortholimnobium. Lindbergia 2018, 41, 1-7. [CrossRef]

38. Lefebvre, J. Étude Comparative Des Plagiotheciacea de Belgique a l'égard de Certains Facteurs Influencant Leur Relation Hydrique Avec Le Milieu [Comparative Study of Plagiotheciacea from Belgium with Regard to Certain Factors Influencing Their Water Relationship with the Environment]. Bull. Soc. Roy. Bot. Belg. 1970, 103, 63-70.

39. Lefebvre, J. Étude autécologique des Plagiotheciaceae de Belgique. [Autecological study of Plagiotheciaceae from Belgium]. Bull. Soc. Roy. Bot. Belg. 1970, 103, 51-62.

40. Szweykowski, J.; Zieliński, R. Isoenzymatic Variation in Polish Population of the Moss Plagiothecium undulatum (Hedw.) B.S.G.-A Preliminary Report. J. Hattori Bot. Lab. 1983, 54, 119-123.

41. Inoue, S.; Iwatsuki, Z. Cytotaxonomic Studies of Plagiothecium B.S.G. and its Related Genera. J. Hattori Bot. Lab. 1987, 63, 453-471.

42. Hofman, A. A Preliminary Survey of Allozyme Variation in the Genus Plagiothecium (Plagiotheciaceae, Bryopsida). J. Hattori Bot. Lab. 1988, 64, 143-150.

43. Frey, W.; Kürschner, H. Conspectus Bryophytorum Orientalum et Arabicorum. An Annotated Catalogue of the Bryophytes of Southwest Asia; J. Cramer in der Gebrüder Borntraeger Verlagsbuchhandlung: Berlin-Stuttgart, Germany, 1991.

44. Frey, W.; Kürschner, H. New Records of Bryophytes from Afghanistan-With a Note on the Bryological Exploration of the Country. Nova Hedwig. 2009, 88, 503-511. [CrossRef] 
45. Kürschner, H.; Frey, W. Liverworts, Mosses and Hornworts of Southwest Asia (Marchantiophyta, Bryophyta, Anthoceroptophyta). Nova Hedwig. 2011, 139, 179-180.

46. Kürschner, H.; Frey, W. Liverworts, Mosses and Hornworts of Afghanistan-Our Present Knowledge. Acta Mus. Siles. Sci. Nat. 2019, 68, 11-24. [CrossRef]

47. Ros, R.M.; Mazimpaka, V.; Abou-Salama, U.; Aleffi, M.; Blockeel, T.L.; Brugués, M.; Cros, R.M.; Dia, M.G.; Dirkse, G.M.; Draper, I.; et al. Mosses of the Mediterranean, an Annotated Checklist. Cryptogam. Bryol. 2013, 34, 99-283. [CrossRef]

48. Hodgetts, N.G. Checklist and Country Status of European Bryophytes-Towards a New Red List for Europe. Irish Wildlife Manuals, No. 84; National Parks and Wildlife Service, Department of Arts, Heritage and the Gaeltacht: Dublin, Ireland, 2015.

49. Sabovljević, M.; Natcheva, R.; Dihoru, G.; Tsakiri, E.; Dragićević, S.; Erdağ, A.; Papp, B. Check-List of the Mosses of SE Europe. Phytol. Balcan. 2008, 14, 207-244.

50. Marka, J.; Blockeel, T.L.; Long, D.G.; Papp, B. Bryophytes New to Albania from the British Bryological Society Field Meeting in 2014. J. Bryol. 2018, 40, 163-172. [CrossRef]

51. Sérgio, C.; Brugués, M.; Cros, R.M.; Casas, C.; Garcia, C. The Red List and an Updated Checklist of Bryophytes of the Iberian Peninsula (Portugal, Spain and Andorra). Lindbergia 2006, 31, 108-124.

52. Sotiaux, A.; Vanderpoorten, A. A Checklist of the Bryophytes of Andorra. J. Bryol. 2017, 39, 353-367. [CrossRef]

53. Manakyan, V.A. Results of Bryological Studies in Armenia. Arctoa 1995, 5, 15-33. [CrossRef]

54. Köckinger, H.; Schröck, C.; Krisai, R.; Zechmeister, H.G. Checklist of Austrian Bryophytes (a Continuously Updated Checklist). [Online Source]. Available online: https:/ / cvl.univie.ac.at/projekte/moose/ (accessed on 19 March 2021).

55. Frahm, J.-P. An Evaluation of the Bryophyte Flora of the Azores. Bryophyt. Divers. EVolume 2005, 26, 57-79. [CrossRef]

56. Gabriel, R.; Sjögren, E.; Schumacker, R.; Sérgio, C.; Aranda, S.C.; Claro, D.; Homem, N.; Martins, B. List of Bryophytes (Anthocerotophyta, Marchantiophyta, Bryophyta). In A List of the Terrestrial and Marine Biota from the Azores; Borges, P.A.V., Costa, A., Cunha, R., Gabriel, R., Gonçalves, V., Martins, A.F., Melo, I., Parente, M., Raposeiro, P., Rodrigues, P., et al., Eds.; Princípia: Cascais, Portugal, 2010; pp. 99-115.

57. Gabriel, R.; Homem, N.; Couto, A.; Aranda, S.C.; Borges, P.A.V. Azorean Bryophytes: A Preliminary Review of Rarity Patterns. Açoreana 2011, 7, 149-206.

58. Cros, R.M.; Sáez, L.; Brugués, M. The Bryophytes of the Balearic Islands: An Annotated Checklist. J. Bryol. 2008, 30, 74-95. [CrossRef]

59. O'Shea, B.J. An Overview of the Mosses of Bangladesh, with a Revised Checklist. J. Hattori Bot. Lab. 2003, 93, 259-272.

60. Banu-Fattah, K.; Sarker, S.K. Bryophyte Flora of Greater Mymensingh District of Bangladesh-Class: Bryopsida. Bangladesh J. Plant Taxon. 2007, 14, 47-66. [CrossRef]

61. Shabeta, M.S.; Rykovsky, G.F. Bryophyte Diversity in The Belarus Coniferous Forests. Arctoa 2015, 24, 541-546. [CrossRef]

62. Sotiaux, A.; Pioli, A.; Royaud, A.; Schumacker, R.; Vanderpoorten, A. A Checklist of the Bryophytes of Corsica (France): New Records and a Review of the Literature. J. Bryol. 2007, 29, 41-53. [CrossRef]

63. Long, D.G. Mosses of Bhutan II *. A Checklist of the Mosses of Bhutan. J. Bryol. 1994, 18, 339-364. [CrossRef]

64. Asthana, A.K.; Sahu, V. Two New Records of Plagiothecium from India. Acta Bot. Hung. 2015, 57, 1-6. [CrossRef]

65. Suleiman, M.; Akiyama, H.; Tan, B.C. A Revised Catalogue of Mosses Reported from Borneo. J. Hattori Bot. Lab. 2006, 99, 107-183. [CrossRef]

66. Higuchi, M.; Yao, K.-Y.; Lin, S.-H. Mosses of Mt. Chilai, Taiwan. Mem. Natl. Sci. Mus. Tokyo 2012, 48, 159-175.

67. Tan, B.C.; Mohamed, H. A New Moss Checklist of Negara Brunei Darussalam. Pol. Bot. J. 2013, 58, 259-266. [CrossRef]

68. Natcheva, R.; Ganeva, A. Check-List of the Bryophytes of Bulgaria. II. Musci. Cryptogam. Bryol. 2005, 26, $209-232$.

69. Tixier, P. Bryophytae Indosinicae. A Preliminary Contribution to the Bryoflora of Angkhor (Cambodia). Nat. Hist. Bull. Siam Soc. 1966, 21, 129-133.

70. Tixier, P. A Preliminary Contribution to the Knowledge of the Coastal Southern Bryoflora of Cambodia. Nat. Hist. Bull. Siam Soc. 1975, 26, 11-24.

71. Tixier, P. Cambodian Bryoflora. Collections from Phnom Kulen. Nova Hedwig. 1980, 32, 369-376.

72. Tan, B.C.; Iwatsuki, Z. A Checklist of Indochinese Mosses. J. Hattori Bot. Lab. 1993, 74, 325-405.

73. Higuchi, M. Moss Flora of Angkor, Cambodia. Bull. Natn. Sci. Mus. Tokyo Ser. B 2009, 35, 141-150.

74. Dirkse, G.; Bouman, A.; Losada-Lima, A. Bryophytes of the Canary Islands: An Annoted Checklist. Cryptogam. Bryol. 1993, 14, 1-47.

75. Dirkse, G.M.; Losada-Lima, A. Additions and Amendments to the Moss Flora of the Canary Island. Cryptogam. Bryol. 2011, 32, 37-41. [CrossRef]

76. He, S.; Redfearn, P.L. Three Mosses New to Mainland China. Bryologist 1995, 98, 383-384. [CrossRef]

77. Redfearn, P.L.; Tan, B.C.; He, S. A Newly Updated and Annotated Checklist of Chines Mosses. J. Hattori Bot. Lab. 1996, 79, 163-357.

78. Park, K.W.; Choe, K. New List of Bryophytes in Korea; Korea National Arboretum: Pocheon, Korea, 2007.

79. Deng-ke, L.; Ireland, R.R. Plagiotheciaceae. In Moss Flora of China; Amblystegiaceae to, Plagiotheciacea; Ren-liang, H., You-fang, W., Crosby, M.R., Eds.; Science Press and Missouri Botanical Garden Press: Beijing, China; St. Louis, MO, USA, 2008; Volume 7, pp. 219-245. 
80. A Checklist of Chinese Mosses. (Date Unknown). Available online: http://www.mobot.org/MOBOT/moss/China/china-p.html (accessed on 3 January 2020).

81. Blockeel, T.L. Notes on Some Rare and Newly Recorded Bryophytes from Crete, Greece. J. Bryol. 2007, 29, 197-198. [CrossRef]

82. Papp, B.; Sabovljević, M. Notes on Some New and Interesting Bryophyte Records from Croatia. J. Bryol. 2009, 31, 272-275. [CrossRef]

83. Papp, B.; Alegro, A.; Šegota, V.; Šapić, I.; Vukelić, J. Additions to the Bryophyte Flora of Croatia. J. Bryol. 2013, 35, 140-143. [CrossRef]

84. Kučera, J.; Váňa, J. Check- and Red List of Bryophytes of the Czech Republic. Preslia 2003, 75, 193-222.

85. Tong, C.; Yuhuan, W. An Enumeration of Bryophytes Collected from North Korea. J. Res. 1998, 9, 226-228. [CrossRef]

86. Kim, J.S.; Kim, S.Y.; Lee, B.Y.; Yoon, Y.J.; Choi, S.S.; Sun, B.Y. A Field Guide to Bryophytes in Korea; National Institute of Biological Resources: Incheon, Korea, 2013.

87. Mogensen, G.S.; Goldberg, I. Danske Navne for Tørvemosser, Sortmosser, og Bladmosser der Forekommer i Danmark. Ver. 4. [Danish and Latin Names for Sphagna, Andreaeas and Mosses that Occur in Denmark. Vers. 4.]; Botanisk Have \& Museum, Københavns Universitet: Copenhagen, Denmark, 2005.

88. Vellak, K.; Ingerpuu, N.; Leis, M.; Ehrlich, L. Annotated Checklist of Estonian Bryophytes. Folia Cryptogam. Est. 2015, 52, 109-127. [CrossRef]

89. Boesen, D.F.; Lewinsky, J.; Rasmussen, L. A Check-List of the Bryophytes of the Faroes. Lindbergia 1975, 3, 69-78.

90. Lewinsky, J.; Jóhansen, J. The Vegetation and Bryophyte Flora of the Faroe Island (Denmark), Excursion Guide; XIV International Botanical Congress: Berlin, Germany, 1987.

91. Koponen, T.; Isoviita, P.; Lammes, T. The Bryophytes of Finland: An Annotated Checklist. Flora Fenn. 1977, 6, 1-77.

92. Plagiothecium B.S.G. in Finland. 1998. Available online: http://www.nic.funet.fi/pub/sci/bio/life/plants/bryophyta/bryopsida/ bryales/plagiotheciaceae/plagiothecium/ (accessed on 2 December 2019).

93. Juutinen, R.; Syrjänen, K.; Korvenpää, T.; Laitinen, P.; Ahonen, I.; Huttunen, S.; Korvenpää, T.; Kypärä, T.; Parnela, A.; Ryömä, R.; et al. Bryophytes. In Suomen Lajien Uhanalaisuus_Punainen Kirja 2019 [The 2019 Red List of Finnish Species]; Hyvärinen, E., Juslén, A., Kemppainen, E., Uddström, A., Liukko, U.-M., Eds.; Finnish Environment Institute: Helsinki, Finland, 2019; ISBN 978-952-11-4974-0.

94. Hugonnot, V.; Celle, J. Première liste rouge des bryophytes d'Auvergne [First red list of Auvergne bryophytes]. Evaxiana 2015, 1, 5-29.

95. Ludwig, G.; Schnittler, M. Rote Liste gefährdeter Pflanzen Deutschlands [Red List of Endangered Plants in Germany]. Schr. Für Veg. Ser. Publ. Veg. Sci. 1996, 28, 1-744.

96. Klawitter, J.; Köstler, H. Rote Liste und Gesamtartenliste der Moose (Bryophyta) von Berlin [Red list and total species list of mosses (Bryophyta) from Berlin]. In Rote Listen der Gefährdeten Pflanzen, Pilze und Tiere von Berlin; Der Landesbeauftragte für Naturschutz und Landschaftspflege/Senatsverwaltung für Umwelt, Verkehr und Klimaschutz, Ed.; Universitätsverlag der Technische Universität (TU): Berlin, Germany, 2017; pp. 1-31.

97. Moose Deutschland (Mosses of Germany). 2017. Available online: http://www.moose-deutschland.de/organismen/?qstring= Plagiothecium (accessed on 7 January 2020).

98. Caspari, S.; Dürhammer, O.; Sauer, M.; Schmidt, C. Rote Liste und Gesamtartenliste der Moose (Anthocerotophyta, Marchantiophyta und Bryophyta) Deutschlands [Red list and total species list of mosses (Anthocerotophyta, Marchantiophyta and Bryophyta) in Germany]. In Rote Liste Gefährdeter Tiere, Pflanzen und Pilze Deutschlands, Band 7: PflanzenPilze [Red List of Endangered Animals, Plants and Fungi of Germany, Volume 7: Plants]; Metzing, D., Hofbauer, N., Ludwig, G., Matzke-Hajek, G., Eds.; Federal Agency for Nature Conservation: Bonn, Germany, 2018; Naturschutz und Biologische Viefalt [Nature conservation and biological diversity]; Volume 70, pp. 361-489, ISBN 978-3-7843-5612-9.

99. Erzberger, P.; Papp, B. Annotated Checklist of Hungarian Mosses. Studia Bot. Hung. 2004, 35, 91-149.

100. Papp, B.; Erzberger, P.; Ódor, P.; Hock, Z.S.; Szövényi, P.; Szurdoki, E.; Tóth, Z. Updated Checklist and Red List of Hungarian Bryophytes. Studia Bot. Hung. 2010, 41, 31-59.

101. Erzberger, P.; Baráth, K. Plagiothecium latebricola a New Member of the Hungarian Bryoflora. Studia Bot. Hung. 2017, 48, 189-197. [CrossRef]

102. Checklist of Icelandic Bryophytes. 2003-2019. Available online: http:/ / www.floraislands.is/Annad/moslist.html (accessed on 10 December 2019).

103. Gangulee, H.C. Mosses of Eastern India and Adjacent Regions; Published by the author: Calcutta, India, 1980 ; Volume 3.

104. Dandotiya, D.; Govindapyari, H.; Suman, S.; Uniyal, P.L. Checklist of the Bryophytes of India. Arch. Bryol. 2011, 88, 71-72.

105. Ho, B.-C.; Tan, B.C.; Hernawati, N.S. A Checklist of Mosses of Sumatra, Indonesia. J. Hattori Bot. Lab. 2006, 100, 143-190.

106. Aziz, F. Seventeen Spp. New Records for the Moss Flora of Iraq. Фhyton 2011, 80, 36-46.

107. Aziz, F.H.; Al-Niama, B. Species Chick [Sic] List of Bryophyte, Pteridophyta, Lichens and Mashroom [Sic] of Iraq and Kurdistan Region. Zanco J. Pure Appl. Sci. 2017, 29, 53-73.

108. Agnew, S.; Vondráček, M. A Moss Flora of Iraq. Feddes Reper. 1975, 86, 341-489. [CrossRef]

109. Hill, M.O.; Preston, C.D.; Bosanquet, S.D.S.; Roy, D.B. BRYOATT-Attributes of British and Irish Mosses, Liverworts and Hornworts With Information on Native Status, Size, Life Form, Life History, Geography and Habitat; Centre for Ecology and Hydrology: Huntingdon, UK, 2007; ISBN 978-1-85531-236-4.

110. Akhani, H.; Kürschner, H. An Annotated and Updated Checklist of the Iranian Bryoflora. Cryptogam. Bryol. 2004, $25,315-347$. 
111. Zare, H.; Akbarinia, M.; Hedenäs, L.; Maassumi, A.A. Eighteen Mosses from the Hyrcanian Forest Region New to Iran. J. Bryol. 2011, 33, 62-65. [CrossRef]

112. Herrnstadt, I.; Heyn, C.C.; Crosby, M.R. A Checklist of the Mosses of Israel. Bryologist 1991, 94, 168-178. [CrossRef]

113. Herrnstadt, I.; Heyn, C.C. Part I. Bryopsida (Mosses). In The Bryophyte Flora of Israel and Adjacent Regions; Flora Palaestina; Heyn, C.C., Herrnstadt, I., Eds.; Israel Academy of Sciences and Humanities: Jerusalem, Israel, 2004; pp. 17-18, ISBN 978-965-208-152-0.

114. Pedrotti, C.C. Flora dei Muschi d'Italia, Parte 2: Bryopsida (II Parte) [Flora of the Mosses of Italy, Part 2: Bryopsida (Second Part)]; Flora dei Muschi d'Italia; Antonio Delfino Editore, Medicina-Scienze: Roma, Italy, 1992; Volume 2, ISBN 978-88-7287-370-0.

115. Aleffi, M.; Tacchi, R.; Pedrotti, C.C. Checklist of the Hornworts, Liverworts and Mosses of Italy. Bocconea 2008, $22,5-254$.

116. Sguazzin, Francesco Check-List Delle Briofite Del Friuli Venezia Giulia (NE Italia) [Check-List of the Bryophytes of Friuli Venezia Giulia (NE Italy). Gortania Bot. Zool 2010, 32, 17-114.

117. Tacchi, R.; Aleffi, M. Mosses and Liverworts of Italy/Muschi Ed Epatiche d'Italia (2011). Available online: http:/ / dryades.units. it/briofite/ (accessed on 26 March 2020).

118. Iwatsuki, Z. New Catalog of the Mosses of Japan. J. Hattori Bot. Lab. 2004, 96, 1-182.

119. Suzuki, T. Many Interesting Mosses Newly Found in Japan. Hattoria 2017, 8, 1-88. [CrossRef]

120. Pantović, J.P.; Sabovljević, M.S. Bryophytes of Kosovo. Phytotaxa 2017, 306, 101-123. [CrossRef]

121. El-Saadawi, W. Some Mosses from Kuwait. Bryologist 1976, 79, 515-518. [CrossRef]

122. Kürschner, H. Bryophyte Flora of the Arabian Peninsula and Socotra; Bryophytorum Bibliotheca; Gebrüder Borntraeger Verlag: Berlin, Germany, 2000; Volume 55, ISBN 978-3-443-62027-1.

123. Ho, B.-C.; Luong, T.-T.; Tan, B.C.; Dinh, N.-L. Additional New and Noteworthy Moss (Bryophyta) Records from Vietnam and Laos. Bryophyt. Divers. EVolume 2015, 37, 1-11. [CrossRef]

124. Ābolina, A. Latvijas sūnu saraksts. [List of bryophytes of Latvia]. Latv. Veǵetācija 2001, 3, 47-86.

125. Ellis, L.T.; Aleffi, M.; Baczkiewicz, A.; Buczkowska, K.; Bambe, B.; Boiko, M.; Zagorodniuk, N.; Brusa, G.; Burghardt, M.; Calleja, J.A.; et al. New National and Regional Bryophyte Records, 60. J. Bryol. 2019, 41, 285-299. [CrossRef]

126. Senn, H. Die Moose Des Fürstentums Liechtenstein [The Mosses of the Principality of Liechtenstein]; Naturkundliche Forschungim Fürstentum Liechtenstein, Regierung des Fürstentums Liechtenstein: Vaduz, Liechtenstein, 2000; Volume 17, ISBN 3-9521855-1-5.

127. Jukonienè, I. Checklist of Lithuanian Mosses [Lietuvos Lapsamanių Sąvadas]. Bot. Lith. 2002, 8, 304-321.

128. Ellis, L.T.; Afonina, O.M.; Doroshina, G.Y.; Agudelo, C.; Andriamiarisoa, R.L.; Asthana, A.K.; Gupta, D.; Gupta, R.; Rawat, K.K.; Sahu, V.; et al. New National and Regional Bryophyte Records, 58. J. Bryol. 2019, 41, 63-84. [CrossRef]

129. Werner, J. Liste rouge des bryophytes du Luxembourg. Mesures de conservation et perspectives. [Red List of the Bryophytes of Luxembourg. Conservation measures and perspectives]. Ferrantia 2003, 35, 9-71.

130. Werner, J. Les bryophytes du Luxembourg — Liste annotée et atlas. [The bryophytes of Luxembourg-annotated list and atlas]. Ferrantia 2011, 65, 12-136.

131. Borges, P.A.V.; Abreu, C.; Aguiar, A.M.F.; Carvalho, P.; Jardim, R.; Melo, I.; Oliveira, P.; Sérgio, C.; Serrano, A.R.M.; Vieira, P. A List of the Terrestrial Fungi, Flora and Fauna of Madeira and Selvagens Archipelagos; Direcção Regional do Ambiente da Madeira and Universidade dos Açores, Funchal and Angra do Heroísmo: Madeira, Portugal, 2008; ISBN 978-989-95790-0-2.

132. Sérgio, C.; Sim-Sim, M.; Carvalho, M. Annotated Catalogue of Madeiran Bryophytes. Bol. Mus. Munic. Funchal 2006, 10 , 5-164.

133. Yong, K.T.; Tan, B.C.; Ho, B.C.; Ho, Q.Y.; Mohamed, H. A Revised Moss Checklist of Peninsular Malaysia and Singapore; FRIM Research Pamphlet Series; Forest Research Institute Malaysia (FRIM): Kuala Lumpur, Malaysia, 2013; Volume 133, ISBN 978-967-5221-99-6.

134. Ellis, L.T. Some Mosses New to the Maldives. J. Bryol. 1988, 15, 493-498. [CrossRef]

135. Menzel, M.; Passow-Schindhelm, R. The Mosses of the Maldive Islands. Cryptogam. Bryol. 1990, 11, 363-367.

136. Frahm, J.-P.; Lüth, M. The Bryophyte Flora of the Maltese Islands. Arch. Bryol. 2008, 29, 1-10.

137. Mifsud, S.D. An Update on the Moss Flora of the Maltese Islands. Cryptogam. Bryol. 2012, 33, 405-418. [CrossRef]

138. Karczmarz, K. New and Rare Bryophytes in the Flora of Mongolia. Bryologist 1981, 84, 339-343. [CrossRef]

139. Tsegmed, T. Checklist and Distribution of Mosses in Mongolia. Arctoa 2001, 10, 1-18. [CrossRef]

140. Müller, F.; Wynns, J.T. A Revised Classification of Plagiothecium in Myanmar. J. Bryol. 2020, 42, 169-178. [CrossRef]

141. Karczmarz, K. Bryophytes from Nepal. Lindbergia 1981, 7, 126-130.

142. Kattel, L.P.; Adhikari, M.K. Mosses of Nepal; Natural History Society of Nepal: Kathmandu, Nepal, 1992.

143. Dirkse, G.; van Melick, H.; Touw, A. Checklist of Dutch Bryophytes. Lindbergia 1989, 14, 167-175.

144. Siebel, H.N.; During, H.J.; van Melick, H.M.H. Veranderingen in de Standaardlijst van de Netherlandse Blad-, Lever- En Hauwmossen [Checklist of Dutch Bryophytes and Liverworts]. Buxbaumiella 2005, 73, 26-54.

145. Martinčič, A. Contributions to the Bryophyte Flora of Republic of Macedonia. Hacquetia 2009, 8, 97-114. [CrossRef]

146. Papp, B.; Pantović, J.; Szurdoki, E.; Sabovljević, M.S. New Bryophyte Records for the Republic of Macedonia. J. Bryol. 2016, 38, 168-171. [CrossRef]

147. Noguchi, A. Mosses from Pakistan. J. Hattori Bot. Lab. 1956, 16, 76-82.

148. Karczmarz, K. Bryophytes from Western Jammu and Kashmir. Ann. Univ. Mariae Curie-SkłodowskaC Biol. 1980, $35,34-41$.

149. Higuchi, M. Mosses from Pakistan collected by Botanical Expedition of National Science Museum, Tokyo. In Cryptogamic Flora of Pakistan; Nakaike, T., Malik, S., Eds.; National Sciences Museum: Islamabad, Pakistan, 1992; Volume 1, pp. $245-259$.

150. Nishimura, N.; Watanabe, R.; Kanda, H.; Takaki, N.; Mizushima, U. Pleurocarpous mosses from Pakistan. In Crypotogamic Flora of Pakistan; Nakaike, T., Malik, S., Eds.; National Sciences Museum: Islamabad, Pakistan, 1993; Volume 2, pp. $255-269$. 
151. Higuchi, M.; Nishimura, N. Mosses of Pakistan. J. Hattori Bot. Lab. 2003, 93, 273-291.

152. Iwatsuki, Z.; Tan, B.C. A Tentative Checklist of Philippine Moss Species; Hattori Bot. Lab.: Nichinan, Japan; Univ. of British Columbia: Vancouver, BC, Canada, 1977.

153. Tan, B.C.; Iwatsuki, Z. A New Annotated Philippine Moss Checklist. Harv. Pap. Bot. 1991, 1, 1-64.

154. Ochyra, R.; Żarnowiec, J.; Ochyra-Bednarek, H. Census Catalogue of Polish Mosses. Biodiversity of Poland; Polish Academy of Sciences, Institute of Botany: Kraków, Poland, 2003; Volume 3.

155. Sérgio, C.; Carvalho, S. Annotated Catalogue of Portuguese Bryophytes. Port. Acta Biol. 2003, 21, 5-230.

156. Ellis, L.T.; Afonina, O.M.; Atwood, J.J.; Bednarek-Ochyra, H.; Burghardt, M.; Dragićević, S.; Vuksanović, S.; Espinoza-Prieto, B.; Opisso, J.; Goga, M.; et al. New National and Regional Bryophyte Records, 62. J. Bryol. 2020, 42, 195-208. [CrossRef]

157. Kürschner, H.; Alatalo, J.M.; Al-Mesaifrib, M.A.S.L.; Alsafran, S.A. Closing a Gap-First Records of Bryophytes from the Qatar Peninsula. Cryptogam. Bryol. 2018, 39, 77-82. [CrossRef]

158. Ştefănuţ, S.; Goia, I. Checklist and Red List of Bryophytes of Romania. Nova Hedwig. 2012, 95, 59-104. [CrossRef]

159. Ignatov, M.S.; Afonina, O.M. Check-List of Mosses of the Former USSR. Arctoa 1992, 1, 1-85. [CrossRef]

160. Ellis, L.T.; Aleffi, M.; Asthana, A.K.; Srivastava, A.; Bakalin, V.A.; Batan, N.; Özdemir, T.; Bednarek-Ochyra, H.; Borovichev, E.A.; Brugués, M.; et al. New National and Regional Bryophyte Records, 40. J. Bryol. 2014, 36, 223-244. [CrossRef]

161. Cherdantseva, V.; Pisarenko, O.; Ignatov, M.; Ignatova, E.; Fedosov, V.; Dudov, S.; Bakalin, V. Mosses of the Southern Russian Far East, an Annotated Check-List. Bot. Pac. 2018, 7, 1-29. [CrossRef]

162. Moss Flora of Russia. (Date Unknown). Available online: http:/ /www.arctoa.ru/Flora/spisok-vidov.htm (accessed on 10 December 2019).

163. Flora of Slovakia. (Date Unknown). [Online Source] Slovakia: Institute of Botany SAS (The Institute of Botany of the Slovak Academy of Sciences). Available online: www.ibot.sav.sk/checklist/index.php?lang=en\&doc=list (accessed on 25 December 2019).

164. Mišíková, K.; Godovičová, K.; Širka, P.; Šoltés, R. Checklist and Red List of Mosses (Bryophyta) of Slovakia. Biologia 2020, 75, 21-37. [CrossRef]

165. Skudnik, M.; Sabovljević, A.; Batič, F.; Sabovljević, M. The Bryophyte Diversity of Ljubljana (Slovenia). Pol. Bot. J. 2013, 58, 319-324. [CrossRef]

166. Martinčič, A. Updated Red List of Bryophytes of Slovenia. Hacquetia 2016, 15, 107-126. [CrossRef]

167. Casas, R. New Checklist of Spanish Mosses. Orsis 1991, 6, 3-26.

168. Jansen, M.A.B.; Abeywickrama, B.A. A Checklist of the Mosses of Sri Lanka; National Science Council of Sri Lanka: Colombo, Sri Lanka, 1978.

169. O'Shea, B.J. Checklist of the Mosses of Sri Lanka. J. Hattori Bot. Lab. 2002, 92, 125-164.

170. Ruklani, N.C.S.; Rubasinghe, S.C.K. A Preliminary Survey of Bryophytes in the Central Province of Sri Lanka. Ceylon J. Sci. 2013, 42, 67-72. [CrossRef]

171. Frisvoll, A.A. Fifteen Bryophytes New to Svalbard, Including Notes on Some Rare or Interesting Species. Lindbergia 1981, 7, 91-102.

172. Frisvoll, A.A. The Distribution of Plagiothecium berggrenianum Frisv. Bryologist 1984, 87, 167. [CrossRef]

173. Frisvoll, A.A.; Elvebakk, A. Part 2. Bryophytes. In A Catalogue of Svalbard Plants, Fungi, Algae and Cyanobacteria; Elvebakk, A., Prestrud, P., Eds.; Norwegian Polar Institute: Oslo, Norway, 1996; pp. 57-172.

174. Söderström, L.; Hedenäs, L. Checklista över Sveriges mossor. [Checklist of Swedish Bryophytes]. Myrinia 1998, 8, 58-90.

175. Hallingbäck, T.; Hedenäs, L.; Weibull, H. Ny checklista för Sveriges mossor [New checklist of Swedish bryophytes]. Sven. Bot. Tidskr. 2006, 100, 96-148.

176. Meier, M.K.; Urmi, E.; Schnyder, N.; Bergamini, A.; Hofmann, H. Checkliste der Schweizer Moose. [Checklist of Swiss mosses]; Nationales Inventar der Schweizer Moosflora, Institut für Systematische Botanik der Universität Zürich: Zürich, Switzerland, 2013.

177. Swissbryophytes Working Group 2020. Checkliste. Concept "Swissbryophytes 2017". Available online: https://www. swissbryophytes.ch/index.php/de/datenzentrum/checkliste (accessed on 30 December 2019).

178. Kuo, C.-M.; Chiang, T.Y. Index of Taiwan Mosses. Taiwania 1987, 32, 119-207.

179. He, S. An Annotated Checklist and Atlas of the Mosses of Thailand. 1995-2014. Available online: http://www.mobot.org/ MOBOT/moss/Thailand/thai-p.shtml (accessed on 3 January 2020).

180. Cetin, B. Checklist of the Mosses of Turkey. Lindbergia 1988, 14, 15-23.

181. Uyar, G.; Çetin, B. A New Check-List of the Mosses of Turkey. J. Bryol. 2004, 26, 203-220. [CrossRef]

182. Ellis, L.; Asthana, A.; Sahu, V.; Bednarek-Ochyra, H.; Ochyra, R.; Cano, M.; Costa, D.; Cykowska-Marzencka, B.; Philippov, D.; Dulin, M.; et al. New National and Regional Bryophyte Records, 25. J. Bryol. 2010, 32, 311-322. [CrossRef]

183. Bolyukh, V. A Comparison of Moss Flora of Central Podolia (Ukraine) and Adjacent Regions. Arctoa 1995, 4, 45-54. [CrossRef]

184. Virchenko, V. A List of Pleurocarpous Mosses of Ukraine; National Academy of Sciences of Ukraine, MH Kholodny Institute of Botany: Kiev, Ukraine, 2000.

185. Virchenko, V. МохоподібніПриродно-Заповідних Територій Українського Полісся. [Bryophytes of protected areas of the Ukrainian Polissya]; TOV NVP “Interservis": Kiev, Ukraine, 2014.

186. Aleffi, M. The Bryophyte Flora of the Vatican City State. Cryptogam. Bryol. 2015, 36, 155-169. [CrossRef] 
187. Aleffi, M. Contribution to the Knowledge of the Bryophyte Flora of the Vatican City State: The Pontifical Villas of Castel Gandolfo (Rome, Italy). Flora Medit. 2017, 27, 137-150. [CrossRef]

188. Ninh, T. Mosses of the Tam Dao Mountains, Vietnam. Bryologist 1993, 96, 573-581. [CrossRef]

189. He, S.; Khang, N.S. New Records and an Updated Checklist of the Mosses of Vietnam. Bryophyt. Divers. EVolume 2012, $34,32-88$. [CrossRef]

190. Kürschner, H. A Bryophyte Flora of Socotra Island, Yemen. In Biodiversity of Socotra Forests, Woodlands and Bryophyte; Kilian, N., Hubaishan, M.A., Eds.; Englera. No. 28.; Botanischer Garten und Botanisches Museum (BGBM): Berlin-Dahlem, Germany, 2006; pp. 97-162, ISBN 0170-4818.

191. Wolski, G.J. Reassessing the Taxonomic Diversity of Plagiothecium Section Orthophyllum in the North American Bryoflora. Brittonia 2020, 72, 337-350. [CrossRef]

192. Mitten, W. Musci Indiae Orientalis; an Enumeration of the Mosses of the East Indies; Journal of the Proceedings of the Linnean Society, Supplement to Botany. No. 1; Longman, Brown, Green, Longmans \& Roberts, and Williams and Norgate: London, UK, 1859.

193. Müller, C. Struckia, Eine Neue Laubmoos-Gattung [Struckia, a New Genus of Deciduous Moss]. Arch. Des Ver. Der Freunde Der Nat. Mecklenbg. 1894, 47, 127-130.

194. Greene, S.W. The British Species of the Plagiothecium denticulatum-P. silvaticum Group. Trans. Brit. Bryol. Soc. 1957, 3, 181-190. [CrossRef]

195. Sofronova, E.N.; Abakarova, A.S.; Afonina, O.M.; Badmaeva, N.K.; Borovichev, E.A.; Boychuk, M.A.; Czernyadjeva, I.V.; Doroshina, G.Y.; Dulin, M.V.; Dyachenko, A.P.; et al. New Bryophyte Records. 1-Новые Бриологические Находки. 1. Arctoa 2012, 21, 275-300. [CrossRef]

196. Sofronova, E.V.; Afonina, O.M.; Andrejeva, E.N.; Antipin, V.K.; Baisheva, E.Z.; Bakalin, V.A.; Borovichev, E.A.; Boychuk, M.A.; Czernyadjeva, I.V.; Dulin, M.V.; et al. New Bryophyte Records. 3-Новые Бриологические Находки. 3. Arctoa 2014, $23,219-238$. [CrossRef]

197. Sofronova, E.V.; Afonina, O.M.; Andrejeva, E.N.; Beldiman, L.N.; Bezgodov, A.G.; Borovichev, E.A.; Boychuk, M.A.; Chepinoga, V.V.; Czernyadjeva, I.V.; Doroshina, G.Y.; et al. New Bryophyte Records. 6-Новые Бриологические Находки. 6. Arctoa 2016, 25, 183-228. [CrossRef]

198. Ellis, L.T.; Ah-Peng, C.; Aranda, S.C.; Bednarek-Ochyra, H.; Borovichev, E.A.; Cykowska-Marzencka, B.; Duarte, M.C.; Enroth, J.; Erzberger, P.; Fedosov, V.; et al. New National and Regional Bryophyte Records, 45. J. Bryol. 2015, 37, 308-329. [CrossRef]

199. Islam, M.; Alam, J.; Fiaz, M. A Checklist of Mosses of District Mansehra. Sci. Int. 2016, 28, 2569-2575.

200. Sofronova, E.V.; Andrejeva, E.N.; Bakalin, V.A.; Beldiman, L.N.; Belyakov, E.A.; Blagovetshenskiy, I.V.; Borovichev, E.A.; Boychuk, M.A.; Doroshina, G.Y.; Dulin, M.V.; et al. New Bryophyte Records. 8-Новые Бриологические Находки. 8. Arctoa 2017, 26, 105-125. [CrossRef]

201. Mönkemeyer, W. Die Laubmoose Europas. IV Band Ergänzungsband Andreales—Bryales. In Kryptogamen-Flora von Deutschland, Österreich und der Schweiz; Rabenhorst, L., Ed.; Akademische Verlagsgesellschaft m. b. H. (Druckt von E. Haberland, Leipzig): Leipzig, Germany, 1927.

202. Jedlička, J. Monographia Specierum Europaearum Gen. Plagiothecium s.s.; Priirodovĕdeckou Fakultou Masarykovy University: Brno, Czech, 1948; Volume 308.

203. Jedlička, J. Monographia Specierum Europaearum Gen. Plagiothecium s.s. Icones; Prirodovĕdeckou Fakultou Masarykovy University: Brno, Czech, 1950; Volume 318.

204. Podpéra, J. Conspectus Muscorum Europaeorum; Nakladatelství Československé Akademie Věd: Prague, Czech, 1954.

205. Van der Wijk, R.; Margadant, W.D.; Florschütz, P.A. Index Muscorum; International Bureau for Plant Taxonomy and Nomenclature: Utrecht, The Netherlands, 1967; Volume 4.

206. Sofronova, E.V.; Afonina, O.M.; Akatova, T.V.; Andrejeva, E.N.; Baisheva, E.Z.; Bezgodov, A.G.; Blagovetshenskiy, I.V.; Borovichev, E.A.; Chemeris, E.V.; Chernova, A.M.; et al. New Bryophyte Records. 4-Новые Бриологические Находки. 4. Arctoa 2015, 24, 224-264. [CrossRef]

207. Lewinsky, J.; Mogensen, G. Distribution Maps of Bryophytes in Greenland 4. Lindbergia 1977, 4, $135-142$.

208. Warnstorf, C. Kryptogamenflora der Mark Brandenburg und angrenzender Gebiete. Zweiter Band: Laubmoose [Cryptogamic flora of Mark Brandenburg and adjacent areas. Volume 2: Mosses]; Gebrüder Borntraeger: Leipzig, Germany, 1906.

209. Tan, B.C.; Buck, W.R.; Ignatov, M.S. On the Himalayan Struckia C. Muell. and Russian Cephalocladium Lazar. (Musci, Hypnaceae). Lindbergia 1990, 16, 100-104.

210. Cardot, J.; Thétiot, I. Papers from the Harriman Alaska Expedition XXIX. The Mosses of Alaska. In Proceedings of the Washington Academy of Sciences; Washington Academy of Sciences: Washington, DC, USA, 1902; Volume 4, pp. $293-372$.

211. Sakurai, K. Classification of the Genus Plagiothecium in East Asia. Bot. Mag. 1949, 62, 111-120. [CrossRef]

212. Özdemir, T.; Batan, N. The Bryophyte Checklist of Trabzon Province of Turkey. Arctoa 2017, 26, 58-67. [CrossRef]

213. Ābolina, A.A.; Afonina, O.M.; Badmaeva, N.K.; Bakalin, V.A.; Belkina, O.A.; Borovichev, E.A.; Chemeris, E.V.; Cherdantseva, V.Y.; Cherednichenko, O.V.; Czernyadjeva, I.V.; et al. New Bryophyte Records. Arctoa 2011, 20, 247-268. [CrossRef]

214. Lindberg, S.O. Contributio Ad Flora Cryptogamam Asiae Boreali-Orientalis. Acta Soc. Sci. Fenn. 1872, 10, $221-280$.

215. Fleischer, M. Die Musci der Flora von Buitenzorg: Zugleich Laubmoosflora von Java; E.J. Brill: Leiden, The Netherlands, 1915.

216. Enroth, J. Bryophyte Flora of the Huon Penisula, Papua Nwe Guinea. XLVIII. Plagiotheciaceae (Musci). Ann. Bot. Fenn. 1991, 28, 111-115. 
217. Molendo, L. Bayerns Laubmoose: Vorläufige Übersicht Mit Besonderer Rücksicht Auf Niederbayern; Bericht des Naturhistorischen Vereins in Passau: Passau, Germany, 1875; Volume 10.

218. Kara, R.; Ezer, T.; Düzenlí, A. The Bryophyte Flora of Northern Amanos (Nur) Mountain (Hatay-Turkey). Evansia 2013, 30, 1-14. [CrossRef]

219. Wynns, J.T.; Lange, C.B.A. A Comparison of 16 DNA Regions for Use as Phylogenetic Markers in the Pleurocarpous Moss Genus Plagiothecium (Hypnales). Am. J. Bot. 2014, 101, 652-669. [CrossRef]

220. Sakurai, K. Beobachtungen Über Japanische Moosflora (II). [Observations on Japanese Moss Flora (II)]. Bot. Mag. 1932, 46, 496-509. [CrossRef]

221. Iwatsuki, Z. Catalog of the Mosses of Japan; Hattori Botanical Laboratory: Nichnan, Japan, 1991.

222. Limpricht, K.G. Die Laubmoose Deutschlands, Oesterreichs und der Schweiz [The Mosses of Germany, Austria and Switzerland]; E. Kummer: Leipzig, Germany, 1895; Volume 3.

223. Mitten, W. New Species of Musci Collected in Ceylon by Dr. Thwaites. J. Linn. Soc. Bot. 1873, 13, 293-326. [CrossRef]

224. Ireland, R.R. Buckiella, a New Genus in the Hypnaceae (Musci). Novon 2001, 11, 55-62. [CrossRef]

225. El-Saadawi, W.; Shabbara, H.; Khalil, M.; Taha, M. An Annotated Checklist of Egyptian Mosses. Taeckholmia 2015, 35, 1-23. [CrossRef]

226. Brummitt, R.K. World Geographical Scheme for Recording Plant Distributions, Biodiversity Information Standards (TDWG), 2nd ed.; Hunt Institute for Botanical Documentation Carnegie Mellon University: Pittsburgh, PA, USA, 2001; Available online: http: //www.tdwg.org/standards/109 (accessed on 12 November 2019).

227. Brummitt, R.K.; Powell, C.E. (Eds.) Authors of Plant Names: A List of Authors of Scientific Names of Plants, with Recommended Standard Form of Their Names Including Abbreviations; Royal Botanic Gardens: Kew, UK, 1992; ISBN 0-947643-44-3.

228. Rykovsky, G.F.; Maslovsky, O.M. Flora of Belarus. Bryophytes. Andreaеopsida—Bryopsida; Минск, Тэхналогія[Minsk, Тесhnalogia]: Minsk, Belarus, 2004; Volume 1. 